
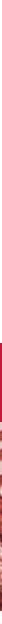

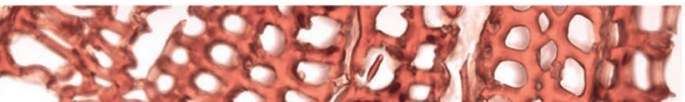
3 -

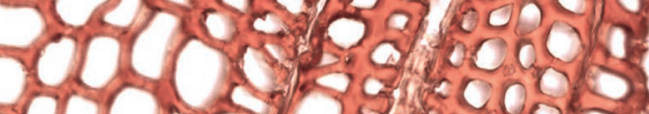

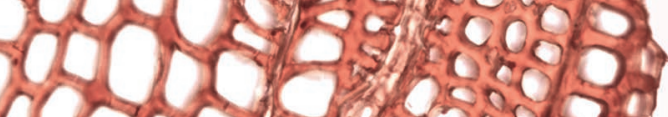

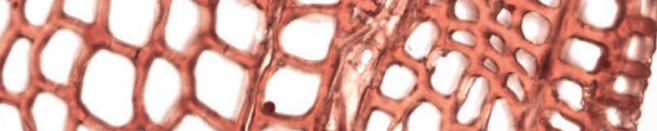

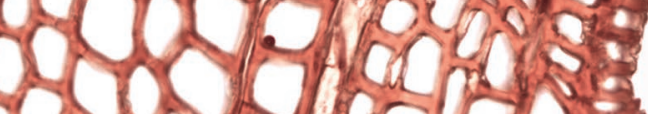

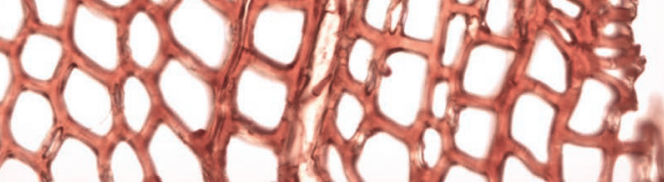
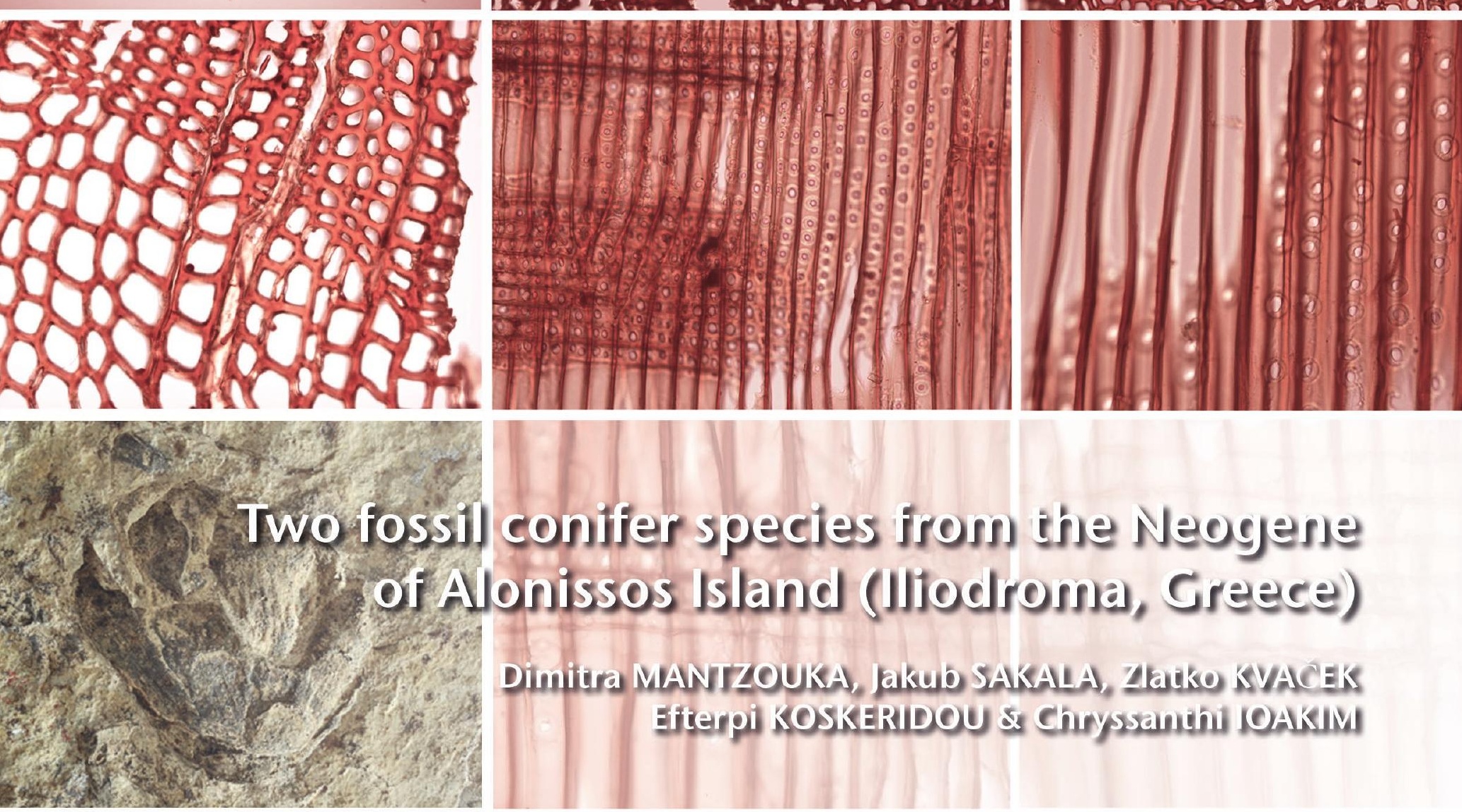

Dimitra NANIZZOUKA), fakub SIAKALA), Lauko SYACEKS Efterpi ROSKERIDCU of Chrysstamini IOAKSIVI
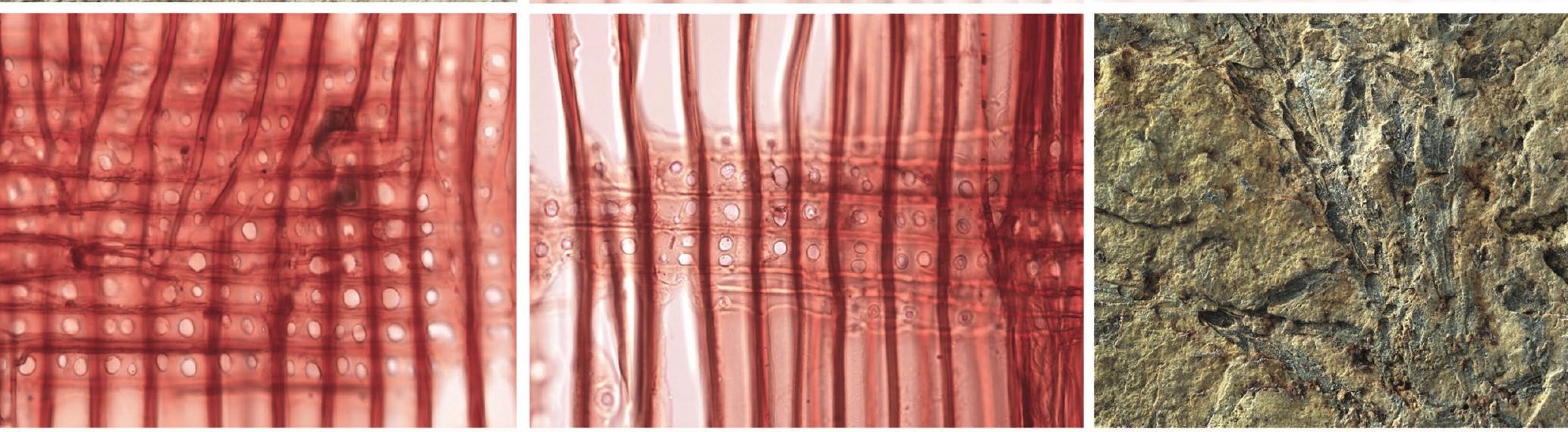
.
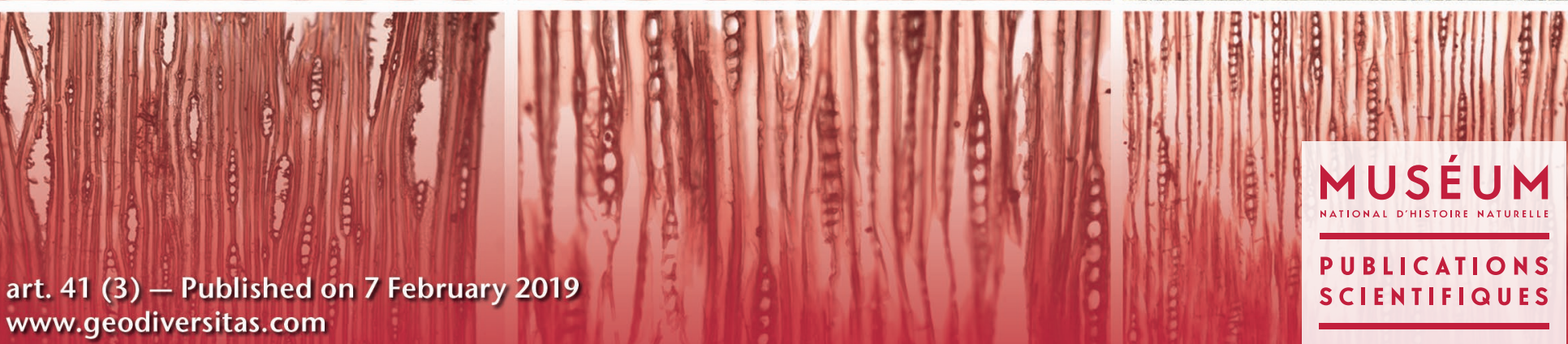
DiRECTEUR DE LA PUBLICATION: Bruno David,

Président du Muséum national d'Histoire naturelle

RÉdACTEUR EN CHEF / EDITOR-IN-CHIEF: Didier Merle

ASSISTANTS DE RÉDACTION / AsSISTANT EDITORS: Emmanuel Côtez (geodiv@mnhn.fr); Anne Mabille

MISE EN PAGE / PAGE LAYOUT: Emmanuel Côtez

COMITÉ SCIENTIFIQUE / SCIENTIFIC BOARD:

Christine Argot (MNHN, Paris)

Beatrix Azanza (Museo Nacional de Ciencias Naturales, Madrid)

Raymond L. Bernor (Howard University, Washington DC)

Alain Blieck (chercheur CNRS retraité, Haubourdin)

Henning Blom (Uppsala University)

Jean Broutin (UPMC, Paris)

Gaël Clément (MNHN, Paris)

Ted Daeschler (Academy of Natural Sciences, Philadelphie)

Bruno David (MNHN, Paris)

Gregory D. Edgecombe (The Natural History Museum, Londres)

Ursula Göhlich (Natural History Museum Vienna)

Jin Meng (American Museum of Natural History, New York)

Brigitte Meyer-Berthaud (CIRAD, Montpellier)

Zhu Min (Chinese Academy of Sciences, Pékin)

Isabelle Rouget (UPMC, Paris)

Sevket Sen (MNHN, Paris)

Stanislav Štamberg (Museum of Eastern Bohemia, Hradec Králové)

Paul Taylor (The Natural History Museum, Londres)

COUVERTURE / COVER

Red colored elements: Pinuxylon alonissianum Mantzouka \& Sakala, sp. nov.; grey color elements: Taxodium europaeum holotype.

Geodiversitas est indexé dans / Geodiversitas is indexed in:

- Science Citation Index Expanded (SciSearch $\left.{ }^{\circledR}\right)$

- ISI Alerting Services ${ }^{\circledR}$

- Current Contents ${ }^{\circledR} /$ Physical, Chemical, and Earth Sciences ${ }^{\circledR}$

- Scopus ${ }^{\circledR}$

Geodiversitas est distribué en version électronique par / Geodiversitas is distributed electronically by:

- BioOne ${ }^{\circledR}$ (http://www.bioone.org)

Les articles ainsi que les nouveautés nomenclaturales publiés dans Geodiversitas sont référencés par / Articles and nomenclatural novelties published in Geodiversitas are referenced by:

- ZooBank ${ }^{\circledR}$ (http://zoobank.org)

Geodiversitas est une revue en flux continu publiée par les Publications scientifiques du Muséum, Paris Geodiversitas is a fast track journal published by the Museum Science Press, Paris

Les Publications scientifiques du Muséum publient aussi / The Museum Science Press also publish:

Adansonia, Zoosystema, Anthropozoologica, European Journal of Taxonomy, Naturae, Cryptogamie sous-sections Algologie, Bryologie, Mycologie.

Diffusion - Publications scientifiques Muséum national d'Histoire naturelle

CP $41-57$ rue Cuvier F-75231 Paris cedex 05 (France)

Tél. : 33 (0)1407948 05 / Fax: 33 (0)14079 3840

diff.pub@mnhn.fr / http://sciencepress.mnhn.fr

(C) Publications scientifiques du Muséum national d'Histoire naturelle, Paris, 2019

ISSN (imprimé / print): 1280-9659/ ISSN (électronique / electronic): 1638-9395 


\section{Two fossil conifer species from the Neogene of Alonissos Island (Iliodroma, Greece)}

Dimitra MANTZOUKA

National and Kapodistrian University of Athens, Faculty of Geology and Geoenvironment, Department of Hist. Geology-Paleontology, Athens (Greece)

dmantzouka@geol.uoa.gr

Jakub SAKALA

Zlatko KVAČEK

Charles University of Prague, Faculty of Science, Institute of Geology and Palaeontology, Albertov 6, 12843, Prague 2 (Czech Republic)

rade@natur.cuni.cz

kvaček@natur.cuni.cz

Efterpi KOSKERIDOU

National and Kapodistrian University of Athens, Faculty of Geology and Geoenvironment, Department of Hist. Geology-Paleontology, Athens (Greece)

ekosker@geol.uoa.gr

Chryssanthi IOAKIM

Institute of Geology and Mineral Exploration, 1st Spirou Louis St., Olympic Village, 13677 Acharnae (Greece) ioakim@igme.gr

Submitted on 10 August 2018 | accepted on 15 October 2018 | published on 7 February 2019

urn:Isid:zoobank.org:pub:0CA44765-DAA0-441D-BCCE-1EC1B369164F

Mantzouka D., Sakala J., Kvaček Z., Koskeridou E. \& loakim Chr. 2019. - Two fossil conifer species from the Neogene of Alonissos Island (lliodroma, Greece). Geodiversitas 41 (3): 125-142. https://doi.org/10.5252/geodiversitas2019v41a3. http://geodiversitas.com/41/3

\section{ABSTRACT}

Alonissos (Iliodroma) Island is really famous to palaeobotanists because of the type locality of Glyptostrobus europaeus (Brongniart) Unger only. Since the first report of the latter holotype no palaeobotanical work has taken place in Alonissos. This is the first research of the fossiliferous locality, along with new palaeobotanical, palynological and gastropod findings, revealed after 200 years. Among the collected material, a xylitic specimen was studied and identified as Pinuxylon alonissianum Mantzouka \& Sakala, sp. nov. The presence of this species points to botanical affinities with sections of Diploxylon Pines (Pinus leiophylla var. chibuahuana (Engelm.) Shaw, P. arizonica Engelm., P. arizonica var. cooperi (C.E.Blanco) Farjon, P. engelmannii Carrière and P. jeffreyi Balf.) especially from Central America (Sierra Madre Occidental and Oriental of Mexico, Arizona, California, Oregon and Sierra

KEY WORDS Alonissos (Iliodroma) Glyptostrobus europaeus, fossil wood anatomy,

Diploxylon Pines, new species. Nevada). This is the first research of this kind revealing as the Nearest Relative bioprovince of the studied Greek fossil pine wood Central America and not Himalayas or Asia. Moreover, a palynological study and an analysis of fossil molluscs were carried out for the first time, giving more data regarding the palaeovegetation and palaeoclimate of the area. Finally, the holotype of Glyptostrobus europaeus (Brongniart) Unger, housed in the collections of the Muséum national d'Histoire naturelle, Paris (MNHN), is found, photographed and presented for the first time. 


MOTS CLÉS
Île d'Alonissos
(Liadrómia),
Glyptostrobus europaeus,
anatomie du bois fossile,
conifere,
pins de type Diploxylon,
espèce nouvelle.

T'A CLES

Liadrómia) is fossile, èce nouvelle.

\section{RÉSUMÉ}

Deux espèces de coniferes fossiles du Néogène de l'île d'Alonissos (Liadrómia, Grèce). L'île d'Alonissos (Liadrómia) est connue par les paléobotanistes comme le gisement type de Glyptostrobus europaeus (Brongnart) Unger. Cette recherche est la première présentant de nouvelles découvertes en paléobotanique, en palynologie et sur les gastropodes de ce site fossilifère depuis 200 ans. Parmi les restes fossiles, un spécimen xylitique est étudié et identifié comme Pinuxylon alonissianum Mantzouka \& Sakala, sp. nov. Ce taxon présente des affinités avec les pins de type Diploxylon (Pinus leiophylla var. chihuahuana (Engelm.) Shaw, P. arizonica Engelm., P. arizonica var. cooperi (C.E.Blanco) Farjon, P. engelmannii Carrière and $P$. jeffreyi Balf.) de l'Amérique centrale en particulier (Mexique: Sierra Madre occidentale et orientale, Arizona, Californie, Oregon, Sierra Nevada). C'est la première affiliation de ce genre à des pinacées fossiles en Grèce. Ce travail sur la pinède grecque révèle qu'elle est plus proche de la bioprovince d'Amérique centrale que de celle de l'Himalaya ou de l'Asie. De plus l'analyse palynologique et des mollusques associés apporte de nouvelles informations sur la couverture végétale et l'environnement de la région. Finalement, l'holotype de Glyptostrobus europaeus (Brongniart) Unger a été redécouvert dans les collections du Muséum national d'Histoire naturelle, Paris, photographié et présenté en détail pour la première fois.

\section{INTRODUCTION}

Alonissos Island has been a geological attraction from the $3^{\text {rd }}$ century B.C. with the findings of giant skeletons accompanied by myths. During the $19^{\text {th }}$ century the explorations for mineral resources had lead the famous geologists of the time to visit the Island. The discovery of lignite had also generated the interest of the palaeobotanists for the palaeoflora of the island. Among the palaeofloristic findings was the first occurrence (the holotype) of Taxodium europaeum Brongniart. This species was later revised by Unger and classified as Glyptostrobus europaeus (Brongniart) Unger. During this study there was an effort of revealing the exact locality where this species had been found almost 200 years ago and presenting new information concerning the palaeobotany of Alonissos Island.

\section{GEOLOGY AND LOCALITY}

Alonissos (or Iliodroma or Chilidromia or Chelidromi) is a long, narrow, mountainous island belonging to the North Sporades, situated close to the Magnesian peninsula (Thessaly - Volos) at the South-eastern of Euboea Island (Fig. 1).

The geology of the island is studied by several scientists (e.g. Virlet 1833; Schneider 1972; Kelepertsis 1973, 1975; Pe-Piper et al. 1996; Poulimenos \& Karkanas 1998; Papanikolaou et al. 2002; Evelpidou et al. 2013) and extensively discussed in Jacobshagen \& Matarangas (2004), from the bottom to the top consists of (Fig. 2):

\section{Pelagonian Unit}

Composed of meta-carbonates of up to $500 \mathrm{~m}$ thickness (light grayish color, thin- to medium-bedded dolomitic in the bottom of Triasso-Jurassic age and calcitic marbles nearly unbedded at the top). According to Kelepertsis
$(1973,1975)$ the age of the upper part of the succession is Kimmeridgian (Upper Jurassic) as proved by the following fossils: Cladocoropsis sp., Clypeina sp., Ellipsactinia, Pseudocyclammina sp., Trocholina sp., Nerinea Defrance, 1824.

\section{EOHELLENIC NAPPE RELICS}

Composed of grayish phyllites and calcschists, with intercalations of thin-bedded black marbles and quartzites (metaturbidites).

\section{MeSOAUTOCHTHONOUS COMPLEX}

With an 8-meters unit of Basal Conglomerates of Albian or Cenomanian age resting upon a karstic relief (which contains relics of metabauxite filling in places) and the overlying Rudist Limestones with thick bedded to massive, roughly recrystallised grayish marbles of several hundred meters thickness of Cenomanian-Turonian age.

\section{PALOUKI FORMATION}

Overlies the Pelagonian marbles or the Eohellenic metabasites, respectively, with tectonical contacts and includes an alternation of marbles, metasandstones, and schists.

\section{NEOGENE DEPOSITS}

Consisting of conglomerates, limestones and marls, lignitic formation and reddish clastics.

Concerning the Neogene, in Kelepertsis study (1975) for the Institute of Geology \& Mineral Exploration (I.G.M.E.), the Neogene formations of Alonissos Island include Pontian red clays and continental conglomerates overlying the formation of the marls, clays and limestones interbedded by thin layers of lignite. Pontian some decades ago was treated as a part of Pliocene but today this concept has been revised and Pontian stage belongs to the late Miocene period (upper Tortonian-Messinian, see in Popov et al. 2006: fig.1). Inside these red clays mammal remains have 
Quaternary

Neogene

Palouki Unit

Flysch

Palouki carbonates

Mesoautochthonous Complex

Rudist limestones

$\because \because$ Basal conglomerates

Pelagonian Unit

Pelagonian marbles

एD Meta clastics with carbonate lenses

Eohellenic Outliers
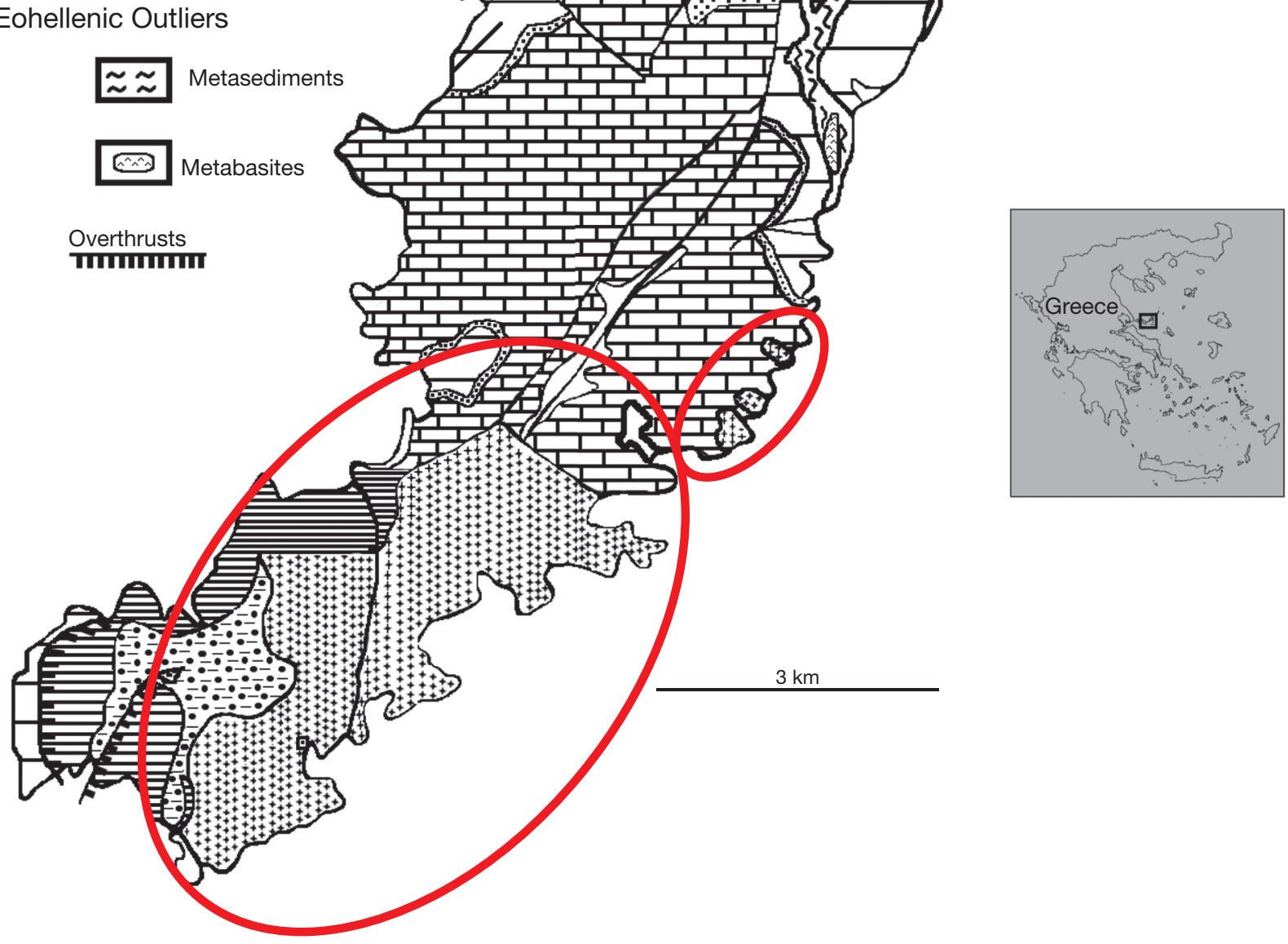

FIG. 1. - Geological sketch - map of Alonissos Island, by Jacobshagen \& Matarangas (2004) (based on the work of Kelepertsis [1975] for the Institute of Geology and Mineral Exploration [I.G.M.E.]), modified. The Neogene formations are included by the red circles. 


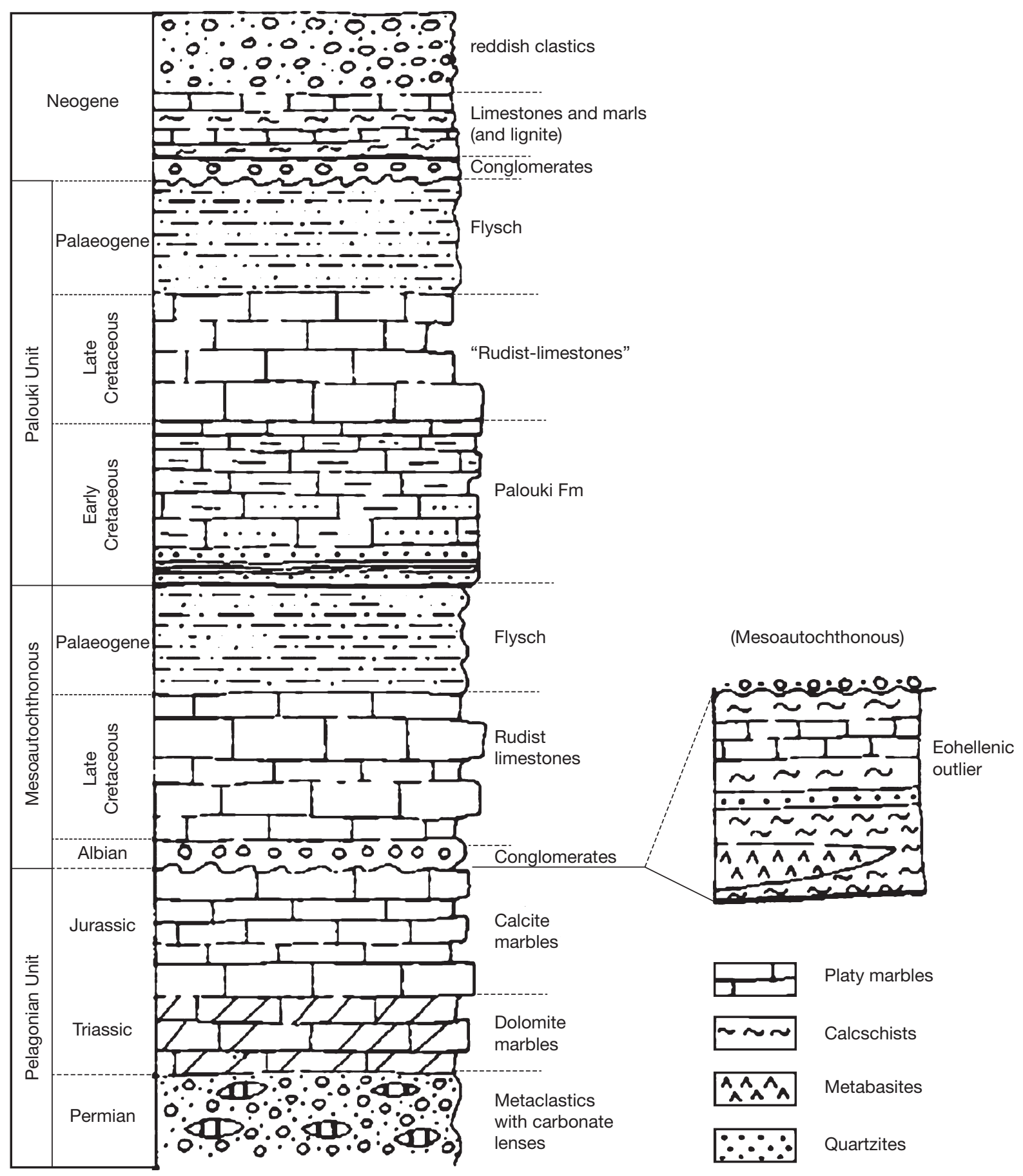

FIG. 2. - Tectonostratigraphic column of Alonissos island (according to Jacobshagen \& Matarangas 2004, modified).

been found (e.g., Schneider [1972] had found the upper jaw of Hipparion Christol, 1832). Consequently the plant fossiliferous layer is early-middle Miocene in age, although the age of the plant fossiliferous layer as proposed by Mai (1995) and LePage (2007) is Burdigalian, early Miocene. This latter layer includes also Planorbis sp., Massylaea of. vermiculata (O.F. Müller, 1774), Melanopsis buccinoidea (Olivier, 1801) and fresh water ostracodes (Kelepertsis 1975).
Virlet (1835) had described the geological formations of Alonissos Island (from the bottom to the top) with a detailed description of the Neogene as follows: 1) micaslate, clay-slate and limestone; 2) blue and grey limestone; and 3) a fresh water tertiary formation containing lignites which occupies half of the surface of the island, and was mistaken for coal. The lower part of the last formation is situated 200 or 300 meters above the sea, and is constituted of blue or green marls with a great deposit of fresh water and 

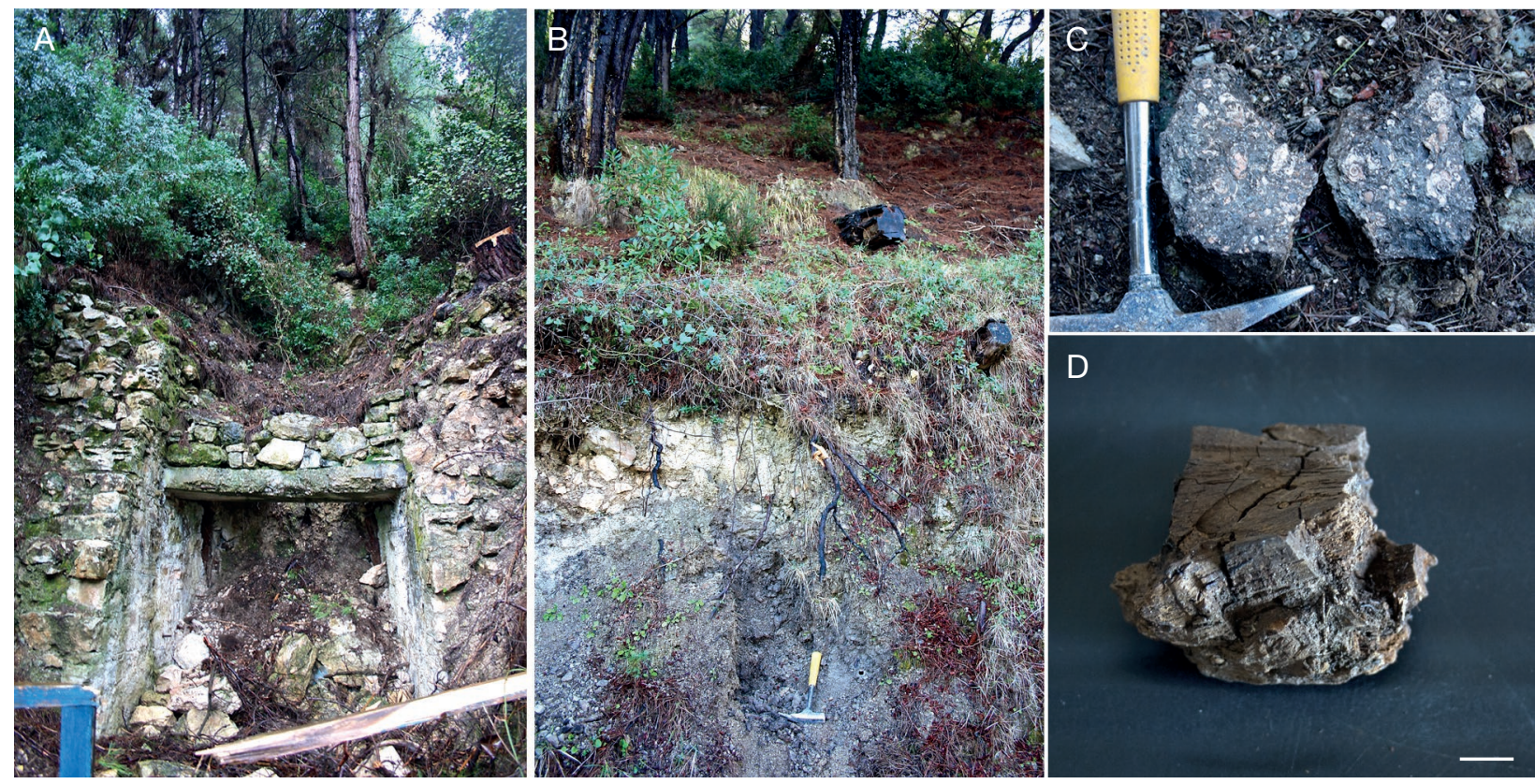

FIG. 3. - A, Abandoned quarry where the lignite was exported from; B, section with the fossil gastropods layer (bottom), the lignite and the plant fossiliferous marls (top); C, gastropod fossiliferous samples; D, lignite sample (DMALNS6) studied microscopically and found that belonged to Pinuxylon Gothan, identified as Pinuxylon alonissianum Mantzouka \& Sakala, sp. nov. Scale bar: D, $1 \mathrm{~cm}$.

land shells belonging chiefly to the genera Planorbis O.F. Müller, 1774, Viviparus Montfort, 1810, Helix Linnaeus, 1758. Over these marls lie thin strata of marly limestone without fossils, containing a lignite layer of about 0.6 meters, intermixed with clay and shells. Above the lignite grey marls occur, filled with the debris of fossil plants. The whole succession is about 58 meters in thickness. Among the fossils obtained from this formation, the most numerous belonged to a species examined by Adolphe Théodore Brongniart and named by him as Taxodium europaeum.

Almost 200 years after the first reference about the lignitic horizon and Taxodium europaeum finding and taking into account the publication of the 19th century (e.g., Brongniart 1833, 1861; Virlet 1833, 1835; Gaudry 1860) we found the locality where the lignite and the plant fossils were hosted, in a close distance of Votsi village (Fig. 3A, B).

\section{MATERIAL AND METHODS}

More than 80 specimens with gastropods, plant remnants and lignites have been collected from the latter locality (Votsi village, Fig. 3A, B). The specimens we collected from the field have mainly fossil gastropods (intact and fragments, Fig. 3C) and fossil plant remnants which unfortunately cannot be determined (bad preserved and mainly belongings to mixed horizons). The material collected is hosted at the Faculty of Geology and Geoenvironment, National and Kapodistrian University of Athens, Greece.

Among the lignite elements we collected there was a part of a xylite (Fig. 3D). This fossil sample has been boiled in water to become softer, then cut with razor blades and mounted in glycerin jelly (e.g. Gryc \& Sakala 2010). This procedure was followed for its preparation for thin sections in order to be photographed. This process took place at the Faculty of Forestry and Wood Technology, Department of Wood Science, Mendel University in Brno in order to be studied microscopically. The anatomical description has followed the observations by Phillips (1941) and is in accordance with IAWA Softwood List (IAWA Committee 2004).

Unfortunately we were not able to find again Taxodium europaeum or leaves' imprints because the area was an active mine until some decades ago and the plant fossiliferous material situated on the top of the lignite has been disappeared (removed).

After a research we found that the holotype of Taxodium europaeum from Alonissos Island is hosted at the Muséum national d'Histoire naturelle, Paris (MNHN). Therefore we asked for photos of the sample in order to include them at this study (Fig. 4).

The sandy marl sediments from Alonissos Island were sampled for palynological analysis. The technique of pollen extraction (prepared) were wet sieved through $125 \mu \mathrm{m}$ and ultrasonic $10 \mu \mathrm{m}$ sieves and palynomorphs were extracted using $\mathrm{HCl} 30 \%$ and $\mathrm{HF} 40 \%$ to remove carbonate and dissolve silicates. Then treatment with $\mathrm{KOH}$ that dissolve soluble the organic matter of the sediments was applied. The residues were mounted in glycerin gel on microscope slides for analysis under a binocular NIKON transmission microscope and one or two slides of each processed sample were analyzed at $\times 500$ and $\times 1000$ magnification (oil immersion). Pollen grains, terrestrial spore and algae cysts 
were identified and counted following the methods and taxonomy of Iversen (Faegri \& Iversen 1989). Percentage of pollen and cysts taxa have been calculated on the basis of minimum sums of 400 specimens (most samples). Four hundred palynomorphs were included in the quantitative analysis.

For the molluscs analysis, the bulk samples were dried and then soaked for $24 \mathrm{~h}$ in diluted hydrogen peroxide. They were subsequently wet sieved through a series of strainers with three different mesh sizes $(2000,1000,500 \mu \mathrm{m})$. The molluscs (fragments mostly) were picked and identified. The studied gastropod taxonomy follows the FreshGEN database (Neubauer et al. 2014) and ecological information was based on the assumed preferred ecological requirements outlined by Fechter \& Falkner (1990) and Glöer (2002).

\section{HISTORY OF THE RECOGNITION AND IDENTIFICATION OF THE PLANT AND ANIMAL FOSSILS IN ALONISSOS ISLAND}

Philostratus (3 ${ }^{\text {rd }}$ century B.C.), the ancient Greek philosopher from Lemnos Island, has given two descriptions about a giant skeleton of a mammal in Alonissos island, Greece (of about $5.5 \mathrm{~m}$ long) declared as one of the giants of the Gigantomachy, and in Imbros island (Imroz), Turkey (the last one has been found and identified as a Miocene mastodon) (Philostratus: On Heroes in Mayor 2000 and Higgins \& Higgins 1996). In 1971 the archaeological research has revealed the skeletons of Miocene hipparion and rhinoceros close to the ancient village Ikos (Aupert 1976). Schneider (1972) refers to a Pontian mammal fauna of the Island including Hipparion indicative of a late Messinian age.

During the $19^{\text {th }}$ century the research for the discovery of energy sources (e.g. coal) in Greece was widespread. Virlet had visited Greece soon after was said to have been observed coal. He visited the Sporades Septentrionales or Devil's Archipelago, situated at the mouth of the Gulfs of Volo and Salonica, near the coasts of Thessaly and Macedonia, where it was incorrectly said coal existed (Virlet 1833).

According to Brongniart (1833), Virlet had collected a lot of plant fossils (especially leaf imprints) in a site not far from Kymi (Euboea) and because of the quantity of the findings he presented it as the analogue of Pikermi for the plants.

M. Gaudry (1860) in his letters to M. Elie de Beaumont reports the existence of Taxodium europaeum in Kymi underlying the fact that this species was described by Brongniart from his work on Morea (Greece) and it was reported by M. Virlet at Iliodroma island, close to Euboea.

Unger (1862) in his work 'Reise in Griechenland' has a reference on the fossil plants from Chelidhromi (as was the name of Alonissos) Island found inside the same 'freshwater formation' with the one of Kymi, Euboea. Unger had studied the work by Virlet (1833) and Gaudry (1860) who believed that the age of the fossiliferous formation is the same with the one of Kymi, Kalamos, Markopoulo and Oropos and not older than Miocene (as also reported in Sauvage 1861 and Brongniart 1861).

\section{SYSTEMATICS/RESULTS}

Alonissos (Iliodroma) Island is really famous to the palaeobotanists because of the first report of Glyptostrobus europaeus (Brongniart) Unger. The holotype of the fossil today is preserved on a marly limestone slab of the following dimensions (in $\mathrm{cm}$ ): $15 \times 10$, from Alonissos Island, Greece and is hosted in the palaeontological collections of the MNHN with the code MNHN.F.1744 (Fig. 4). The fossil was recognized, described and named as Taxodium europaeum (basionym) by Brongniart (1833).

Brongniart (1833) in his famous description of the fossil is talking about complete fossils of the species and about numerous findings. The holotype MNHN.F.1744 is represented by one complete sample which we believe that fits identically to Brongniart's description.

\section{Family CUPRESSACEAE sensu lato Genus Glyptostrobus Endlicher}

Glyptostrobus europaeus (Brongniart) Unger (Fig. 4A-F)

Taxodium europaeum Brongniart, 1833: 168 (Iliodroma = Alonissos). Taxodites europaeus - Endlicher 1847: 278 (Iliodroma = Alonissos). Glyptostrobus europaeus - Unger 1850: 434 (Iliodroma and others). - Schneider \& Velitzelos 1973: 246, pl. 35, fig. 1 (Vegora). Velitzelos \& Schneider 1977: 173, figs 1-3 (Vegora). — Mai \& Velitzelos 1997: 510, pl. 4, figs 1-4 (Vegora).

Original DiaGNOSIS. - "Ramis fastigiatis, elongatis, gracilibus: Foliis subtristichis, alternis, brevissimis, basi decurrentibus, apice acutiusculis: Strabilis subglobosis vel ovoideis: Squamis sub octofariis, disco terminali, margine superne armato, crenato, medio crista transversali prominente partito, saliis radiantibus in parte superiore notato" (Brongniart 1833: 168-176).

\section{DESCRIPTION}

According to the new study of the holotype the following characteristics have been observed: Branched twigs with cupressoid foliage (Fig. 4A). No taxodioid foliage was observed. Ripe cone (male) $1.6 \mathrm{~cm}$ long and it consists of about 16 elongated imbricated scales (Fig. 4B). Branches/ shoots with leaves scale-like, cupressoid type (or even linearsubulate as discussed in Ma et al. 2013) or if one follows the terminology by Vickulin et al. (2003) the leaves are squamate with cupressoid appearance, helically/spirally arranged or even slightly decussate. The leaves are short (leaf length: $1-2 \mathrm{~cm}$ and width: $0.5-1 \mathrm{~cm}$ ) and their apex is not mucronate as in the modern $G$. pensilis but globose to broadly ovoid/concave (Fig. 4D, F). Cones (Fig. 4C, D) and perennial branchlets/shoots with cupressoid foliage (Fig. 4E) are observed.

\section{DisCussion}

According to Kvaček et al. (2002), Glyptostrobus in Euboea develops relatively smaller cones and heteromorphic foli- 

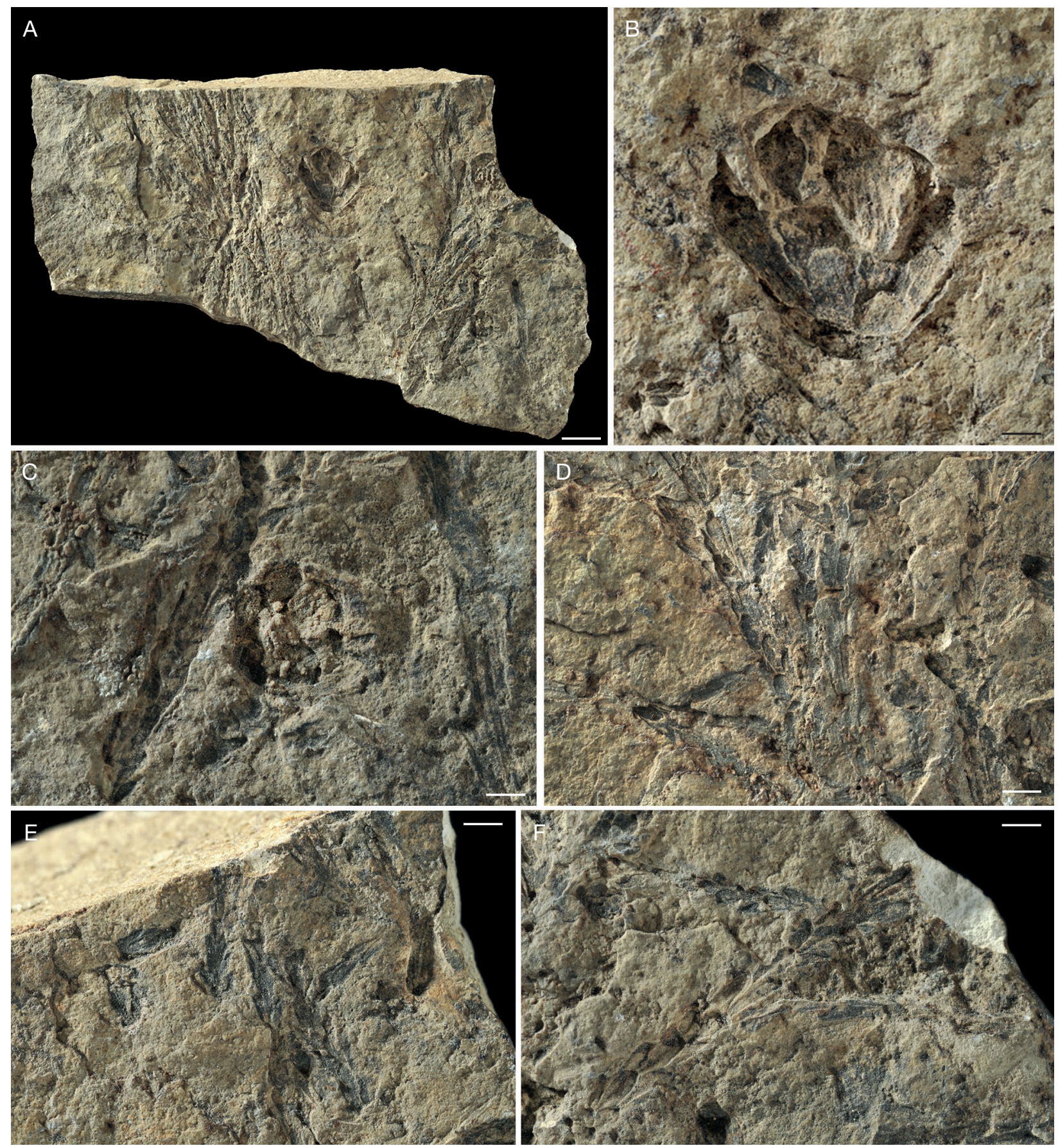

FIG. 4. - Glyptostrobus europaeus (Brongniart) Unger: A-F, Taxodium europaeum holotype, hosted in the collections of the MNHN (Paris) with the code MNHN.F.1744; A, branched twigs with cupressoid foliage; B, ripe cone (male) $1.6 \mathrm{~cm}$ long consisting of about 16 elongated imbricated scales; C, D, cones; D, F, short leaves (length: $1-2 \mathrm{~cm}$; width: $0.5-1 \mathrm{~cm}$ ) with globose to broadly ovoid/concave apex; E, perennial branchlets / shoots with cupressoid foliage. Scale bars: A, $1 \mathrm{~cm}$; B, C, E, F, $0.2 \mathrm{~cm} ; \mathrm{D}, 0.25 \mathrm{~cm}$.

age, which is in contrast to Early Miocene specimens from Central Europe.

Glyptostrobus europaeus represents a species found in several localities in Greece during the Cainozoic. Apart from the findings of this species from Kymi (Euboea Island) and Alonissos Island of Burdigalian age (Early Miocene) and from Vegora (Macedonia) of Messinian age (Upper Miocene) given in LePage (2007: 393), the geographical distribution of this species in Greece includes additional localities (Velitzelos et al. 2014), such as Aliveri and Nea Styra (Euboea Island) and Moudros (Lemnos Island) of Burdigalian age, Komnina (Macedonia), Platana (Western Peloponnese), Prosilio and Lava (Kozani, eastern West Macedonia), Likoudi and Drymos (Elassona, Northern Thessaly) and Iliokomi-Kormitsa (Strymon BasinThrace) of Upper Miocene (Messinian) age, Crete (Makrilia) of Middle Tortonian age, Pikermi-Chomateri (Attica) of 
Tortonian-Messinian age, Ptolemaida (West Macedonia) of Lower Pliocene age, Skoura (Sparti, Laconia) of Pliocene age, Kolymbia (Rhodes) of Pleistocene age.

According to Manchester (1999), Glyptostrobus has a continuous presentation at the fossil floras of Europe from the Palaeocene until the Pliocene/Pleistocene, of North America during Palaeocene, Eocene and Miocene and a constant one from Palaeocene to present in Asia.

Glyptostrobus europaeus taxonomic and biogeographic history started in Canada (Aptian) and is given in detail in LePage (2007). Unfortunately, the assignment of the fossil conifer described in Li et al. (2018) to Glyptostrobus europaeus is considered ambiguous because the sample has seed cones falling into scales, a characteristic not in accordance with any known fossil representative of Glyptostrobus europaeus until now. Recent studies (Dolezych \& van der Burgh 2004) had correlated for the first time Glyptostrobus europaeus with Glyptostroboxylon rudolphii Dolezych \& van der Burgh. Numerous information for the "whole-plant" reconstruction of the species providing by the connection between fossil stumps, trunks and twigs of the taxon are also given in Vassio et al. (2008) or by an indirect association of different organs within the same site (Teodoridis \& Sakala 2008).

Glyptostrobus pensilis Koch is the only extant species in its genus inhabited today in SE China, Viet Nam and Lao PDR (Henry \& McIntyre 1926; Farjon \& Filer 2013).

Among the newly collected specimens we were able to identify a xylitic remnant with anatomical characteristics resembling a conifer. Its microscopical study is also presented below.

\section{CONIFERS}

\section{Family PINACEAE L.}

Genus Pinuxylon Gothan

Pinuxylon alonissianum Mantzouka \& Sakala, sp. nov. (Figs 3D; 5A-O)

Plant Fossil Names Registry Number: PFN000281

HolotyPE. - Designated here. Specimen DMALNS6 (Repository: Museum of Geology and Palaeontology in the National and Kapodistrian University of Athens).

ETyMology. - The epithet, alonissianum, is due to the origin of the described material (Alonissos Island, Greece).

TYPE HORIZON. - Lignite horizon.

AgE. — Early Miocene.

TyPe LOCALITY. - Votsi, Central Alonissos Island, Greece.
DiAGNOSE. - Coniferous wood with distinct growth ring boundaries, gradual transition from early to latewood, thin walled latewood tracheids, axial and radial resin canals (mainly at the latewood), thin-walled epithelial cells, bordered pits in radial walls with welldefined disc-shaped torus, no axial parenchyma observed, rays: exclusively uniseriate, fusiform rays with average height of rays 4-12 $(-20)$ cells, tracheid pits uniseriate, ray tracheids present with up to four rows of cells, cell walls of ray tracheids smooth and occasionally slightly dentate, ray tracheid pit borders with dentate thickenings, horizontal and end walls of ray parenchyma cells smooth, no indentures observed, cross-field pitting pinoid in 1-2 rows of 1-2 (-6) pits per cross-field.

\section{DESCRIPTION}

Macroscopic description

The sample belongs to a xylitic remnant of dark brown colour with the following dimensions: $6 \times 5 \times 4 \mathrm{~cm}$ (Fig. 3D).

\section{Microscopic description}

Transverse section. Growth ring boundaries distinct, transition from early- to latewood gradual (Fig. 5A), latewood tracheids thin walled (Fig. 5A-D), large resin canals (axial and radial distributed but mainly at the latewood) with thin-walled epithelial cells (Fig. 5-C), bordered pits in radial walls with well-defined disc-shaped torus (Fig. 5D), no axial parenchyma observed.

Tangential section. Exclusively uniseriate rays (fusiform because they contain radial intercellular canals and have a specific shape), average height of rays 4-12 cells (mostly "medium" sized but they can be up to 20 cells). Resin canals in rays with thin-walled epithelial cells (Fig. 5L-O).

Radial section. Tracheid pits uniseriate (Fig. 5E, F). Ray tracheids present with up to four rows of cells (Fig. 5G, H, K), cell walls of ray tracheids smooth (Fig. 5G, K) and occasionally slightly dentate (Fig. 5G-I), ray tracheid pit borders with dentate thickenings (Fig. 5I). End walls of ray parenchyma cells smooth (Fig. 5J, K). Horizontal walls of ray parenchyma cells smooth (Fig. 5J, K), no indentures were observed, cross-field pitting pinoid in 1-2 rows of usually 1-2 pits per cross-field but up to 6 (Fig. $5 \mathrm{E}, \mathrm{G}, \mathrm{H}, \mathrm{J}, \mathrm{K}$ ).

\section{DISCUSSION ON THE WOOD ANATOMICAL CHARACTERISTICS}

The occurrence of thin walled resin canals (axial and radial), the absence of parenchyma cells, the uniseriate tracheid pitting, the pinoid cross-field pitting, the existence of ray tracheids, the smooth horizontal and end walls of ray parenchyma indicate that our fossil belongs to Pinaceae and more precisely to the genus Pinus L.

The cell walls of ray tracheids of our sample have been described as "smooth and occasionally slightly dentate" following the terminology by Ickert-Bond (2001: 361) and in

FIG. 5. - Pinuxylon alonissianum Mantzouka \& Sakala, sp. nov.: A, growth ring boundaries distinct, transition from early- to latewood gradual, latewood tracheids thin walled, large resin canals with thin-walled epithelial cells; $\mathbf{B}$, growth ring boundaries distinct, latewood tracheids thin walled, large resin canals (axial and radial) with thin-walled epithelial cells; C, latewood tracheids thin walled, large resin canals with thin-walled epithelial cells; $\mathbf{D}$, growth ring boundaries distinct, latewood tracheids thin walled, bordered pits in radial walls with well-defined disc-shaped torus; $\mathbf{E}$, cross-field pitting pinoid in horizontal 2 rows of usually $1-2$ pits per cross-field but up to 6; F, bordered pits in radial tracheid walls uniseriate; $\mathbf{G}$, tracheid pits uniseriate. ray tracheids with up to four rows of cells, cell walls of ray tracheids smooth and slightly dentate (white arrows), cross-field pitting pinoid in 2 rows of usually 1-2 pits per cross-field but up to 6; H, tracheid pits uniseriate. 

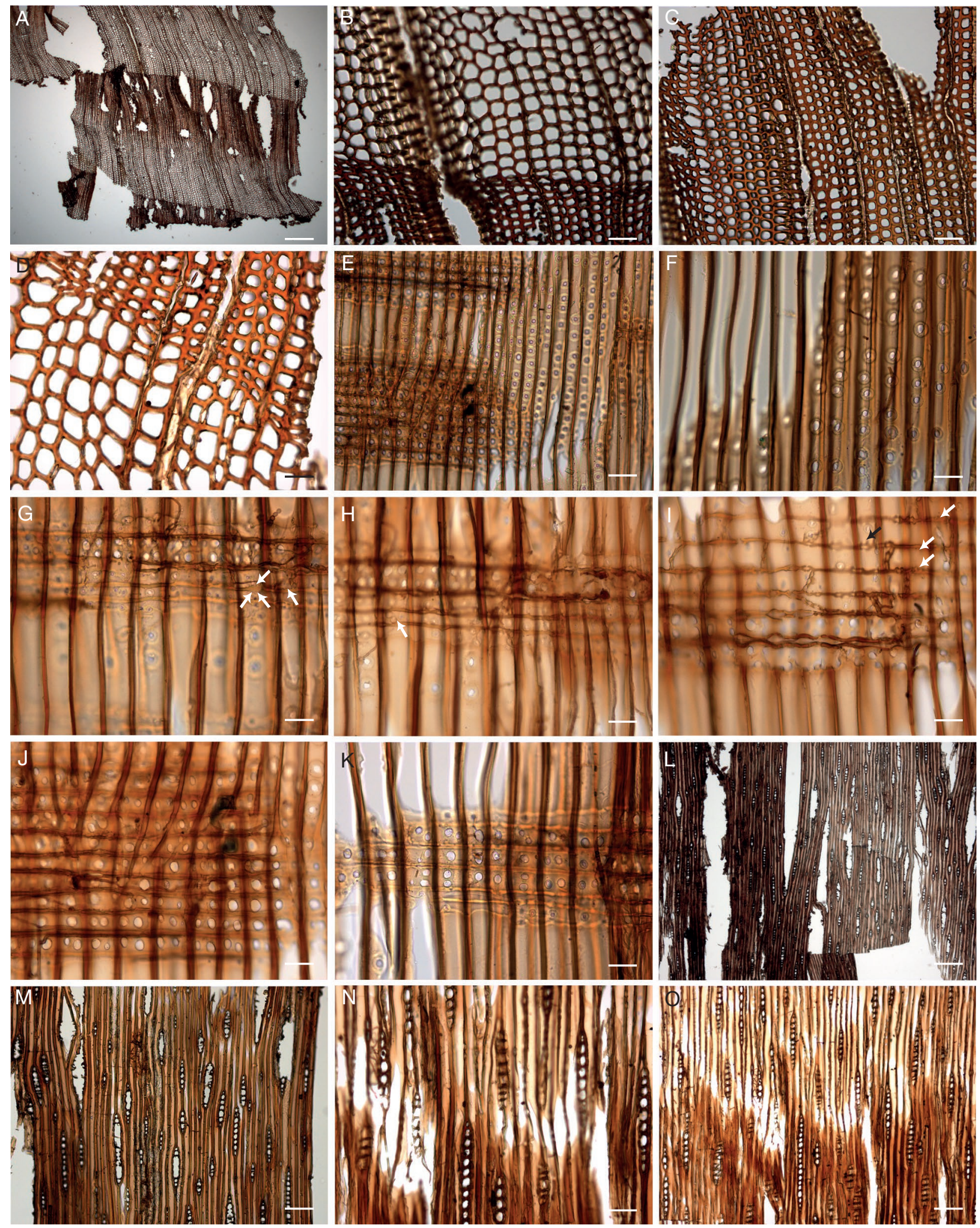

Ray tracheids with up to four rows of cells, cell walls of ray tracheids slightly dentate (white arrow), cross-field pitting pinoid in 2 horizontal rows of usually $1-2$ pits per cross-field but up to 6 ; I, cell walls of ray tracheids slightly dentate (white arrows), ray tracheid pit borders with dentate thickenings (black arrow); $\mathbf{J}$, end walls of ray parenchyma cells smooth, horizontal walls of ray parenchyma cells smooth, cross-field pitting pinoid in 1-2 rows of usually $1-2$ pits per cross-field but up to 6; K tracheid pits uniseriate. Ray tracheids with up to four rows of cells, cell walls of ray tracheids smooth, end walls of ray parenchyma cells smooth, horizontal walls of ray parenchyma cells smooth, cross-field pitting pinoid in 1-2 rows of usually 1-2 pits per cross-field but up to 6; L-O, exclusively uniseriate rays (fusiform because they contain radial intercellular canals and have a specific shape), average height of rays 4-12 cells (mostly "medium"sized but they can be up to 20 cells). Resin canals in rays with thin-walled epithelial cells. A-D, transversal section; E-K, radial longitudinal sections; L-O, tangential longitudinal sections. Scale bars: A, $400 \mu \mathrm{m}$; B, C, E, N, $50 \mu \mathrm{m}$; D, F-K, $25 \mu \mathrm{m}$; L, $200 \mu \mathrm{m} ; \mathrm{M}, \mathrm{O}, 100 \mu \mathrm{m}$. 
accordance with the "smooth as well as slightly dentate ray tracheids" as discussed in van der Burgh (1964: 254-259; 1973: 104-106) and in Dolezych et al. (2011: 53). The same kind of identification of the cell walls of ray tracheids has been pointed out as "inconspicuously dentate" in Phillips (1941: 265, feature 17, pl. 15, fig. 30, judging from the "thickest parts") and as "less prominent (and with outer tracheid walls typically sinuous) dentate" (cause the term "smooth" is used only for generally thin walls with no ornamentation at all) discussed in IAWA Committee (2004: 43, feature 82).

In Greece a lot of fossil pine remnants have been found (e.g. Velitzelos et al. 2014; Zidianakis et al. 2016) but only a few pine fossils in the form of wood have been identified until now. Moreover, the fossil pine cones and seeds from Greece have been related to Pinus roxburghii Sarg. and P. canariensis C.Sm. (Mai \& Velitzelos 2002, 2007; Boyd 2009; Kvaček et al. 2014).

Our specimen has been compared with the fossil pine woods from Greece and has been found to have a lot of differences with them: Pinoxylon parenchymatosum Süss \& Velitzelos (Süss \& Velitzelos 1993) from Lemnos Island is characterized by the occurrence of axial parenchyma, a feature not in accordance with our fossil. Pinoxylon paradoxum Süss \& Velitzelos (Süss \& Velitzelos 1994) from Lesbos Island is characterized by the existence of spirals and $P$. pseudoparadoxum (Süss \& Velitzelos 1994, Lesbos Island) has high rays - up to 50 - cells. Our specimen differs also from two more species from Lesbos Island identified by Süss \& Velitzelos (2009): from Lesbosoxylon (= Pinoxylon) diversiradiatum Süss \& Velitzelos because the latter one has bi-seriate rays and from L. (= Pinoxylon) graciliradiatum Süss \& Velitzelos which has large rays with "idioblast-like" cells. There are also differences with Lesbosoxylon (= Pinoxylon) ventricosuradiatum Süss \& Velitzelos (e.g. rays with "idioblast-like" cells and pits in the cross-field and ray tracheids not ascertainable) (Süss \& Velitzelos 2010). Our specimen has also been compared with Pinuxylon sp. cf. Pinus sylvestris L. (Iamandei et al. 2011, 2016) and found different because the fossil from the Romanian Carpathians has axial parenchyma and 2-3-seriate rays. It has been also compared with Pinoxylon yabei Shimakura (Shimakura 1936) which is completely different from our fossil having axial parenchyma, bordered pits arranged in three rows, thick-walled epithelial cells of resin canals, occurrence of traumatic canals and 1-3 seriate rays with up to 70 cells height.

Our fossil has dentate horizontal walls of ray tracheids, therefore it is assigned to Diploxylon pines. So, we immediately reject from comparison the fossil pine woods belonging to Haploxylon type. Wang et al. (2017) have made a list including the majority of the fossil pine woods described in literature and their characteristics. This study has divided their list in two categories: a) Haploxylon; and b) Diploxylon pines.

\section{Haploxylon}

The fossil Haploxylon pines (with smooth horizontal walls of ray tracheids as also seen in Wang et al. 2017: table 1) which are rejected from being correlated with our fossil are the following: Pinus uniseriata H.B.Wang, A.A.Oskolski \&
Z.K.Zhou (Wang et al. 2017), P. albicauloides S.K.Choi \& K.Kim (Choi et al. 2010), Pinuxylon chemrylensis Blokhina (Blokhina 1995), Pinoxylon dakotense Knowlton emend. Read (Nishida \& Nishida 1995), Pinuxylon cembraeforme Rössler (Rössler 1937), P. microporosum Ogura (Nishida \& Nishida 1995) or P. microporum Ogura (Ogura 1944), which has no ray tracheids (and as also discussed in Blokhina \& Bondarenko [2016] shouldn't be assigned to Pinuxylon), P. similkameenensis Miller (Miller 1973), Pinuxylon sp. (Tao et al. 1994; Zhang et al. 2008 as discussed in Wang et al. 2017), P. woolardii Tidwell, Parker \& Folkman (Tidwell et al. 1986), P. zobelianum (Göppert) Kräusel (van der Burgh 1964).

Our research has also revealed some more Haploxylon fossil pine woods not in accordance with our fossil described by: 1) Greguss (1967), Petrescu \& Bican-Brişan (2004) \& Iamandei et al. (2016): Pinuxylon haploxyloides Greguss (only with a single pinoid cross field pit; holotype still available in Budapest, see in Sakala et al. 2018), P. albicauloides Greguss (has only fenestroid cross field pits), P. tarnocziense (Tuzśon) Greguss and Pinuxylon sp.; 2) Dolezych et al. (2011): Pinuxylon succiniferum (Göppert) Kräusel emend. Dolezych; 3) Vozenin-Serra (1971): Pinuxylon nightigalense Vozenin-Serra (as discussed in Iamandei et al. 2016); 4) van der Burgh (1964): Pinuxylon parryoides (Gothan) Kräusel emend. van der Burgh; and 5) Iamandei \& Iamandei (2000): Pinuxylon marinasii Iamandei \& Iamandei.

\section{Diploxylon}

The selected Diploxylon fossil pines of the literature for the purposes of the work by Wang et al. (2017) which have similarities with our fossil wood are: Pinus nanfengensis Wang, Oskolski \& Zhou (Wang et al. 2017), Pinus cf. armandii Franchet (Yi et al. 2005), Pinus hatamuraenase Jeong \& Kim (Jeong et al. 2012), Pinus henanensis J.J.Yang (Yang et al. 1990, 1996; Qi et al. 2005, as discussed in Wang et al. 2017), Pinuxylon arjuzanxianum Huard (Huard 1966; van der Burgh 1973), Pinuxylon eschweilerence van der Burgh (van der Burgh 1973), Pinuxylon halepensoides van der Burgh (van der Burgh 1973), Pinuxylon parryoides (Kräusel) van der Burgh (van der Burgh 1964, 1973; Iamandei 2000), Pinuxylon paxii Kräusel (Rössler 1937; van der Burgh 1973), Pinuxylon pinastroides (Kraus) Stockmans \& Willière (van der Burgh 1973), Pinuxylon ponderosoides van der Burgh (van der Burgh 1973), Pinuxylon taedioides Kräusel (van der Burgh 1964, 1973; former Pinuxylon landensis Huard, 1966), Pinuxylon tarnocziense (Tuzśon) Greguss (van der Burgh 1973), Pinuxylon vateri (Platen) Rössler (Rössler 1937).

P. nanfengensis (Wang et al. 2017) from the late Miocene of the Xianfeng Basin (central Yunnan, southwestern China) is different from our sample in terms of having partially biseriate rays (and not only uniseriate), smooth to slightly pitted ray tracheids and different cross-field pitting (pinoid and taxodioid).

\section{Other similarities}

There are also similarities with the fossil pines from China, i.e., Pinus armandii Franchet (Yi et al. 2002) and P. cf. armandii 
(Yi et al. 2005) which belong to Diploxylon pines of Cembra section but they have different cross-field pitting (fenestroid in 1-2 rows with 1-4 pits instead of pinoid in 1-2 rows and $1-6$ pits in our sample).

Our fossil has similarities with Pinus hatamuraense Jeong \& Kim (Jeong et al. 2012) from the Akita Prefecture but it differs at the height of rays (P. hatamuraense has very long rays up to 32 cells), the fact that our fossil does not have parenchyma but $P$. hatamuraense does and the cross field pitting which, in the case of $P$. hatamuraense, includes also taxodioid pits.

Pinus henanensis J.J.Yang (as described in Wang et al. 2017 because the original sources are published in Chinese only) is also different from our sample having very high rays consisting of up to 33 cells and pinoid and taxodioid cross-field pitting.

Pinuxylon arjuzanxianum Huard (Huard 1966; van der Burgh 1973; Dupéron \& Dupéron-Laudoueneix 1985) is close to our wood but it has 8-9 pits in tangential tracheid walls and up to four pits per cross-field.

Pinuxylon eschweilerence van der Burgh (van der Burgh 1973) has up to two pits per cross-field of pinoid and fenestroid type.

Pinuxylon halepensoides van der Burgh (van der Burgh 1973) differs from our wood in having 7-8 pits in tangential tracheid walls, pits of piceoid, cupressoid and pinoid type and up to two pits per cross-field.

Pinuxylon parryoides (Kräusel) van der Burgh (van der Burgh 1964, 1973; Privé 1972), differs from our wood in having 10-12 pits in tangential tracheid walls, biseriate pits in radial wall of tracheids, pits of pinoid and piceoid type and up to five pits per cross-field.

Pinuxylon paxii Kräusel (Rössler 1937; van der Burgh 1973) has up to two fenestroid pits per cross-field.

Pinuxylon pinastroides (Kraus) Stockmans \& Willière (van der Burgh 1973) differs from our wood in having 10-12 pits in tangential tracheid walls, biseriate pits in radial wall of tracheids, pits of cupressoid, taxodioid and pinoid type and up to four pits per cross-field.

Pinuxylon taedioides Kräusel (van der Burgh 1964, 1973; former Pinuxylon landensis Huard, 1966; Dupéron \& Dupéron-Laudoueneix 1985), differs from our wood in having distinctly dentate horizontal walls of ray tracheids, biseriate pits in radial wall of tracheids, and 1-3 pinoid pits per cross-field.

Pinuxylon tarnocziense (Tuzśon) Greguss (van der Burgh 1973), differs from our wood in having weakly dentate horizontal walls of ray tracheids, biseriate pits in radial wall of tracheids, and 2-3 pinoid pits per cross-field.

Pinuxylon vateri (Platen) Rössler (Rössler 1937) differs from our wood in having taxodioid and pinoid pits per cross-field.

Pinuxylon ponderosoides van der Burgh (van der Burgh 1973) is very close to our sample but it has only up to four pinoid pits per cross field.

As resumed from the aforementioned comparison none of the above-mentioned species was identical to the new finding from Alonissos. Consequently the fossil pine wood from Alonissos Island is declared as a new species, named according the ICBN rules (McNeill et al. 2006: art. 23; art. 60, ICBN Vienna Code) after the place where it was found: Pinuxylon alonissianum Mantzouka \& Sakala, sp. nov.

\section{BOTANICAL AFFINITIES}

The distinction between the sections Pinus (Diploxylon or hard pines) and Strobus (Haploxylon or soft pines) has been discussed more than a hundred years ago (Shaw 1914) and along with the history of the fossil findings of the genus is well documented in $\mathrm{Xu}$ et al. (2015). This divergence took place probably during the mid-Cretaceous (Keeley 2012).

Following the identification key by van der Burgh (1973) we come to the conclusion that our fossil modern relative belongs to one of the following: section Pinaster, or section Sula (P. leucodermis), or section Leiophylla or section Lumholtzii.

Following the classification by Price et al. (1998) and the detailed work of the wood anatomical characteristics of the conifers by Esteban et al. (2004) we examined the modern species belonging to Diploxylon pines (and especially the species of the sections that van der Burgh's identification key had revealed) in order to find the botanical affinities of ours:

1) Section Pinus (Subsection Pinus - because some of the species revealed following van der Burgh's identification key are now belonging to this subsection). Pinus densiflora Siebold \& Zuccarini, P. mugo Turra, P. mugo subsp. uncinata (Ramond) Domin, P. nigra J.F. Arnold, P. resinosa Aiton, $P$. sylvestris L. and $P$. tabuliformis Carrière are excluded because they have 1-2-fenestroid pits per cross-field.

Pinus heldreichii $\mathrm{H}$. Christ has rays very high of up to 30 cells, ray parenchyma with pitted horizontal walls and 1-2 pinoid pits per cross-field.

Pinus kesiya Royle ex Gordon has axial parenchyma.

Pinus massoniana Lambert, P. lumholtzii B.L. Robinson \& Fernald and $P$. pinaster Aiton have biseriate bordered pits on the radial walls of the axial tracheids.

Pinus merkusii Junghuhn \& de Vriese ex de Vriese and P. thunbergii Parlatore have biseriate bordered pits on the radial walls of the axial tracheids and fenestroid cross-field pits.

2) Section Pinus (Subsection Canarienses - Canary Islands, Himalayas). Pinus canariensis C. Smith ex Buch has axial parenchyma and biseriate bordered pits on the radial walls of the axial tracheids.

Pinus roxburghii Sargent (former named as P. longifolia) has biseriate bordered pits on the radial walls of the axial tracheids (Groom \& Rushton 1913).

3) Section Pinus (Subsection Halepenses - S. Europe, W. Asia, N. Africa). Pinus brutia Tenore, is excluded because it has ray parenchyma with nodular end walls and with pitted horizontal walls.

Pinus halepensis Miller is excluded because it has biseriate bordered pits on the radial walls of the axial tracheids and ray parenchyma with nodular end walls and with pitted horizontal walls.

4) Section Pinus (Subsection Pineae-S. Europe). Pinus pinea L. is excluded because it has biseriate bordered pits on the radial walls of the axial tracheids and ray parenchyma with nodular end walls and with pitted horizontal walls. 
5) Section Pinus (Subsection Leiophyllae - Mexico and adjacent SW USA). Pinus leiophylla Schiede ex Schlechtendal \& Chamisso has up to two pinoid pits per cross-field.

P. leiophylla var. chibuahuana (Engelm.) Shaw has up to four pits per cross-field. Therefore we believe that this species could be the modern analogue of our fossil.

6) Section Pinaster. Pinus banksiana Lambert, P. caribaea Morelet, P. clausa (Chapman ex Engelmann) Vasey ex Sargent, P. coulteri D. Don, P. echinata Miller, P. glabra Walter, P. hartwegii Lindley, P. lawsonii Roezl ex Gordon \& Glendinning, P. montezumae Lambert, P. occidentalis Swartz, P. palustris Miller, P. patula Schiede ex Schlectendahl \& Chamisso, P. pseudostrobus Lindley, $P$. pungens Lambert, $P$. radiata $\mathrm{D}$. Don, $P$. rigida Miller, P. sabiniana Douglas ex D.Don, P. serotina Michaux, $P$. taeda L. are excluded because they have biseriate bordered pits on the radial walls of the axial tracheids.

Pinus attenuata Lemmon, P. elliottii Engelmann, P. muricata D. Don, $P$. ponderosa Douglas ex Lawson, $P$. teocote Schiede ex Schlechtendal \& Chamisso, P. torreyana Parry ex Carrière, $P$. virginiana Miller are excluded for having ray parenchyma with nodular end walls and/or with pitted horizontal walls.

Pinus contorta Douglas ex Loudon is excluded for having ray parenchyma with nodular end walls and fenestroid cross-field pits.

From this section it seems that Pinus arizonica Engelmann ex Rothrock, $P$. arizonica var. cooperi (C.E.Blanco) Farjon, $P$. engelmannii Carrière, $P$. jeffreyi Greville \& Balfour could also resemble the modern representatives of our fossil.

\section{PALAEOENVIRONMENTAL DISCUSSION}

\section{ABOUT GLYPTOSTROBUS}

LePage (LePage et al. 2005; LePage 2007) points out that the extinction of Glyptostrobus from North America and Europe along with its increased tolerance in cold and arid environments should most probably be related to increased aridity, decreased global temperature or increased competition for resources from the Pinaceae.

Concerning Glyptostrobus pensilis, Farjon \& Filer (2013) have reported that it occurs in river banks and low lying marshland between 500 and $700 \mathrm{~m}$ a.s.l. in SE China, Viet Nam and Lao PDR and is the only extant species of this genus. The size of the ovulate cones from Kymi (Early Miocene) is smaller and more rounded than the Late Miocene material from the Pannonian area and there are more differences with the only extant species G. pensilis (Stauton ex D. Don) K. Koch.

The modern G. pensilis seems to be more demanding than its ancestor judging from the temperature and precipitation requirements for its occurrence as reported in Fang et al. (2011) (MAT: 18.8 [10.6 23. $\left.0^{\circ} \mathrm{C}\right]$; MTCM: $9.0\left[-0.2 \sim 15.2^{\circ} \mathrm{C}\right]$; MTWM: $27.6\left[21.1 \sim 29.7^{\circ} \mathrm{C}\right]$; ABT: $18.8\left[10.6 \sim 23.0^{\circ} \mathrm{C}\right]$; WI: $166.2\left[79.4-216.2^{\circ} \mathrm{C}\right]$; CI: $0.3\left[0.0 \sim 12.1^{\circ} \mathrm{C}\right]$; PET: 996 [643 1247 mm]; AP: 1526 [950 -2148 mm]; PWQ: 629 [411 1234 mm]; PCQ: 141 [27 -259 mm]; Im: 54.6
[8.0 137.5]; AET: 993 [643 1247 mm]; NPP: 208.2 [95.3 551.6]. The abbreviations are explained as follows: mean annual temperature $\left[\mathrm{MAT},{ }^{\circ} \mathrm{C}\right]$, mean temperature of the coldest month [MTCM, $\left.{ }^{\circ} \mathrm{C}\right]$, mean temperature of the warmest month [MTWM, $\left.{ }^{\circ} \mathrm{C}\right]$, annual biotemperature $\left[\mathrm{ABT},{ }^{\circ} \mathrm{C}\right]$, warmth index $\left[\mathrm{WI},{ }^{\circ} \mathrm{C}\right]$, coldness index $\left[\mathrm{CI},{ }^{\circ} \mathrm{C}\right]$, potential evapotranspiration $[\mathrm{PET}, \mathrm{mm}]$, annual precipitation $[\mathrm{AP}, \mathrm{mm}$ ], precipitation of warmest quarter [PWQ, $\mathrm{mm}$ ], precipitation of coldest quarter [PCQ, $\mathrm{mm}$ ], moisture index $[\mathrm{Im}]$, annual actual evaportranspiration [AET, mm], vegetation net primary productivity [NPP, $\left.\mathrm{g} \cdot \mathrm{a}^{-1} \cdot \mathrm{m}^{-2}\right]$ ).

On the other hand Glyptostrobus europaeus of the Mediterranean region had as the minimum thermic requirements MATmin a temperature of $16.2^{\circ} \mathrm{C}$ (Martinetto et al. 2017) in the warmer and drier south Mediterranean region of the past but had to face climatic, sea level and topogeny changes (e.g. first and third phase of Zanclean flood in Fauquette et al. 1998, 2007; Biltekin et al. 2015). LePage (2007) gives also the preferred habitats of Glyptostrobus, among of which is the lowland swamp to riparian area. This palaeohabitat corresponds perfectly to our case (under the spectrum, of course, of and orogenetic changes).

The characterization of this palaeoenvironment of ours is also supported by Farjon (2005) because Glyptostrobus is known to be tolerant of competition only in environments characterized by wet conditions.

The spectacular morphological stasis of this taxon over a long period of geological time has been stated in several works the last decade, for instance in LePage (2007), in Martinetto et al. (2007, 2015); Martinetto \& Macaluso (2018); Macaluso et al. (2018) concerning the deposits of late Piacenzian age $(2.8 \mathrm{Ma})$ and even Gellasian from Italy, in Teodoridis et al. (2017) where the latter localities where correlated with the ones of the same age from Czech Republic, in Biltekin et al. (2015) concerning the recent Glyptostrobus swamp ecosystems' disappearance from the southern Black Sea shoreline. Concerning the Greek findings similar theories had been already discussed (e.g. Velitzelos \& Gregor 1990) pointing out that Glyptostrobus must have had a dominant role in extant swamps (in basins like Aliveri or Prosilion) mostly representing biotopes of long-time evolvement.

\section{ABOUT PINUXYLON}

As stated above, the xylitic remnant we studied is closer to Pinuxylon arjuzanxianum Huard (Huard 1966; van der Burgh 1973; Dupéron \& Dupéron-Laudoueneix 1985) but not identical, therefore is has been named as $P$. alonissianum Mantzouka \& Sakala, sp. nov. The botanical affinities of this fossil were really interesting including the species Pinus leiophylla var. chibuahuana, P. arizonica, P. arizonica var. cooperi, P. engelmannii and P. jeffreyi.

According to Farjon \& Filer (2013) P. leiophylla var. chihuahuana, is widespread in the Sierra Madre Occidental of Mexico and extends into the southernmost parts of Arizona and New Mexico in the USA being the more northern variety and preferring lower altitudes with drier forest. 

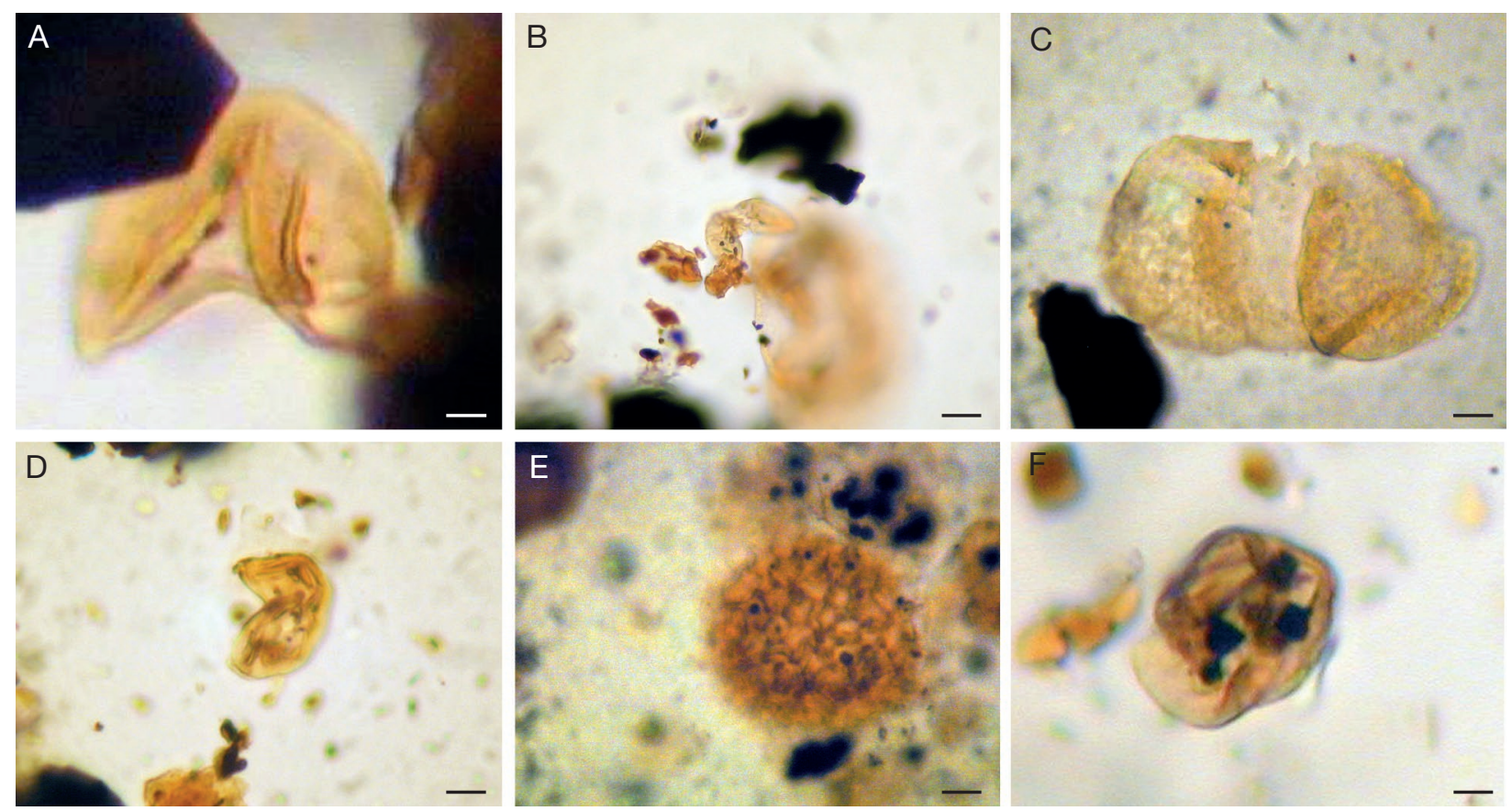

FIG. 6. - Palynology: A, B, D, Taxodiaceae (today part of the Cupressaceae s.I.); C, Pinaceae (Pinus-Diploxylon pollen type sensu Hesse et al. 2006: 22, 23); E, Pteridophyta (Osmundaceae); F, Fagaceae (Quercus). Scale bars: A, F, $2 \mu \mathrm{m}$; B-E, $10 \mu \mathrm{m}$.

According to Farjon \& Filer (2013): Pinus arizonica is a species of the Sierra Madre Oriental and the northern parts of the Sierra Madre Occidental (with var. cooperi), extending into Arizona and New Mexico and possibly in Trans-Pecos Texas living in an environment of moderate rainfalls $(700-900 \mathrm{~mm}$ ) and high altitude (above $2000 \mathrm{~m}$ with the only exception of an isolated population of var. cooperi in the Serranias del Burro in N Coahuila; at only $1300 \mathrm{~m}$ a.s.l). Pinus engelmannii occurs also in the Sierra Madre Occidental, and in the Sierra Madre Oriental as well, in an altitude ranging from 1200 to $3000 \mathrm{~m}$ and is tolerant to cold. Pinus jeffreyi is distributed in California, Oregon, Sierra Nevada, Mexico occurring in mixed coniferous dry and hot environment of middle elevation.

The remarkable specialization of Pinus was the corner stone which lead this genus to survive through great geologic and climatic changes by making adaptations correlated to the environmental conditions (Farjon 1996). The origin and evolution of the genus has been the subject of several works based mostly on the classification of fossil organ findings (e.g. cones, needles and rarely based on fossil wood anatomy) and molecular phylogenetic studies (e.g. Eckert \& Hall 2006; Miller 1976; Price et al. 1998). Moreover the biogeography of this genus has been also the main focus for the establishment of scientific hypotheses, such as the "Gnepine" which indicates that the center of diversity is not necessarily the place of origin (Wang \& Ran 2014) or the interpretation of pine evolution based on fire-prone traits and abiotically stressful habitats (Keeley 2012). This theory could be supported also with the work by Kvaček $\&$ Rember (2000) where the Miocene populations of Glyptostrobus found in North America and in Europe show a close relationship but also independence. Concerning Pinus, although the genus is well diversified in Europe and North America during the Miocene (Kvaček \& Rember 2000) a reliable comparison remains open.

According to Eckert \& Hall (2006) the molecular clocks date the divergence between $P$. jeffreyi-P. arizonica and $P$. engelmannii-P. devoniana at about $17.5 \mathrm{Ma}$, while the separation between $P$. jeffreyi and $P$. arizonica occurred at $10 \mathrm{Ma}$, the separation between $P$. engelmannii and $P$. devoniana occurred before $12.5 \mathrm{Ma}$ as also the separation between $P$. leiophylla and $P$. herrerae.

The co-occurrence of fossil Glyptostrobus (as Glyptostroboxylon) and Pinuxylon has been reported in several works as well, as for instance in the work of Rössler (1937) on the Pliocene coniferous woods around Gleichenberg in Styria (Austria).

What is also interesting is that the plant fossiliferous locality of Alonissos is strongly related to the one of Kymi (Euboea). In Kymi there are a lot of Glyptostrobus europaeus findings as well as pine remnants and a cycadalean foliage described by Saporta (1874). This specimen has been revised by Kvaček \& Velitzelos (2000) as "Encephalartos" gorceixianus Saporta closer to the genus Dioon Lindley growing in Central America and Mexico rather than to Africa (as Saporta [1874] stated). According to Erdei et al. (2010) fossil Encephalartoideae from the Oligo-Miocene of Europe could represent an extinct group of conspecific species of cycads inhabited southern Europe following the trait: Turkey (Pseudodioon akyoli Erdei, Akgün \& Lumaga, 2010) - Greece ("Encephalartos" gorceixianus Saporta) - France ("Zamites" epibius Saporta) - Switzerland ("Zamites" tertiarius Heer). The extratropical area of Sierra Madre Orientale (NE Mexico) is referred in the palaeobotanical literature by Kvaček (2014) as the inhabitant 
of the modern Ceratozamia Brongniart, suggesting subtropical to warm-temperate, almost frostless climate and a high amount of precipitation also to its fossil ancestor.

\section{ABOUT PALAEONTOLOGICAL STUDIES}

The preliminary results of an ongoing study on fossil gastropods from the area supports the palaeoenvironmental conditions of our plant findings as a wet and warm "swampGlyptostrobus" biotope.

The composition of the aquatic gastropod assemblage which is almost monospecific, dominated in species and individual numbers by Planorbarius mantelli (Dunker, 1848) with rare Gyraulus sp. and very rare Pseudamnicola sp., indicate a shallow ephemeral lake.

Extant Planorbarius corneus (Linnaeus, 1758) prefers vegetated, stagnant to slowly running waters, feeding on detritus (Fechter \& Falkner 1990; Glöer 2002) and most Gyraulus species live in stagnant or slowly running waters also.

The freshwater molluscs of the samples, with the very high number of pulmonate gastropods, suggest a shallow and stagnant water body with densely vegetated watersides. The scarceness of fluvial taxa, such as Pseudamnicola sp., indicates a very limited riverine influx.

The composition of the microflora which is enclosed at the studied sediments is characterized by the presence of pollen of trees, shrubs, Poaceae, spores of Pteridophytes and algae of Zygnemataceae (Fig. 6).

The main characteristics of this microflora are the following:

1) a remarkable presence of the pollen of Pinaceae (especially of Pinus type) followed by the taxa of Abies Miller and Tsuga (Endlicher) Carrière in lower percentages. Fossil pollen of Taxodiaceae - Cupressaceae (Inaperturopollenites hiatus Thomson \& Pflug - Glyptostrobus europaeus) was also identified in even lower percentages;

2) angiosperms pollen of trees and shrubs were identified in notable percentages and in great diversity with taxa of Quercus, mainly Q. pubescens Willd. and Q. coccifera-type, Carya Nuttall, cf. Castanea, Nyssa Gronov. ex Linnaeus, Alnus Miller, Pterocarya Nuttall ex Moquin-Tandon, Carpinus L., Corylus L., etc.;

and 3) notable participation of pollen of Poaceae, such as: Gramineae, Compositae, Cruciferae, Polygonaceae, Amaranthaceae-Chenopodiaceae. Spores of Pteridophytes of Lycopodiaceae and Osmundaceae are associated in good percentages.

Moreover, taxa-indicators of aquatic environments along with species of Zygnemataceae algae were identified.

The palynofloristic analysis indicates local vegetation composed of a canopy of conifers dominated by Pinaceae and a minor sub-canopy of Taxodium - Glyptostrobus europaeus, as well as an understory of hydrophilous ferns, mosses and herbaceous angiosperms, indicative of a warm and humid climate in a swampy area.

Finally, the new evidence in combination with the bibliographic data on the palaeobotany of Greece and the Eastern Mediterranean lead to the conclusion that the sediments studied here, were deposited during the Lower Miocene (MN3/MN4 biozone).

\section{Acknowledgements}

Special thanks to the Muséum national d'Histoire naturelle in Paris (MNHN), to Dr Dario de Franceschi and Dr Romain Tomas for making the photo shooting of the holotype and giving us the permission to study it. We also express sincere thanks to Dr Vladimír Gryc, Dr Hanuš Vavrćík and the technicians of the Faculty of Forestry and Wood Technology, Department of Wood Science, Mendel University in Brno for the preparation of the xylitic sample and for providing the microphotos of it. Special thanks to Dr Akindynos Kelepertsis for kindly providing a copy of his PhD and Diamantis Diamantopoulos for providing scientific references from the BNF (Bibliothèque nationale de France). Finally, sincere thanks to Dr Stănilă Iamandei and Dr Marzena Klusek the review of whom improved this work significantly.

\section{REFERENCES}

Aupert P. 1976. - Chronique des fouilles et découvertes archéologiques en Grèce en 1975. Bulletin de correspondance hellénique 100 (2) : 591-745. https://www.persee.fr/doc/bch_00074217_1976_num_100_2_6554

Biltekin D., Popescu S.-M., SuC J.-P., Quézel P., Moreno G. J., YAVUZ N. \& ÇAĞATAY M. N. 2015. - Anatolia: A long-time plant refuge area documented by pollen records over the last 23 million years. Review of Palaeobotany and Palynology 215: 1-22. https://doi.org/10.1016/j.revpalbo.2014.12.004

Blokhina N. I. \& BondarenKo O. V. 2016. — Fossil Wood of Pinus priamurensis sp. nov. (Pinaceae) from the Miocene Deposits of the Erkovetskii Brown Coal Field, Amur Region. Paleontological Journal 50 (3): 311-318. https://doi.org/10.1134/ S0031030116030023

Blokhina N. I. 1995. - Petrified wood of pine Pinuxylon chemrylensis sp.nov., from the Paleogene of Kamchatka. Paleontological Journal 29 (2A): 141-147.

BOYD A. 2009. - Relict conifers from the mid-Pleistocene of Rhodes, Greece. Historical Biology 21: 1-15. https://doi. org/10.1080/08912960903033301

BRONGNIART M. A. 1833. - Notice sur un conifere fossile du terrain d'eau douce de l'île d'Iliodroma. Annales des Sciences naturelles 30: 168-176. https://biodiversitylibrary.org/page/5978683

BRONGNiART M. A. 1861. - Note sur une collection de plantes fossiles recueillies en Grèce par M. Gaudry. Comptes rendus hebdomadaires des Séances de l'Académie des Sciences 52: 12321239. https://gallica.bnf.fr/ark:/12148/bpt6k3009c/f1223.item

Choi S. K., Kim K., JeOng E. K., Terada K., SuZuki M. \& Uematsu H. 2010. - Fossil woods from the Miocene in the Yamagata Prefecture, Japan. IAWA Journal 31 (1): 95-117. https://doi. org/10.1163/22941932-90000009

DOLEZYCH M. \& VAN DER BURGH J. 2004. — Xylotomische untersuchungen an inkohlten Hölzern aus dem Braunkohlentagebau Berzdorf (Oberlausitz, Deutschland). Feddes Repertorium 115 (5-6): 397-437. https://doi.org/10.1002/fedr.200411044

DolezYCh M., Fischer T. \& GRÖSChKe A. 2011. — Pinuxylon succiniferum (Göppert) Kräusel emend. Dolezych - amberized wood from Göppert's type material restudied. Mauritiana (Altenburg) 22: 43-60.

DUNKER W. 1848. — Über die in der Molasse bei Günzberg unfern Ulm vorkommenden Conchylien und Pflanzenreste. Palaeontographica 1 (4): 155-168.

Dupéron J. \& Dupéron-Laudoueneix M. 1985. - Considérations sur les gisements à végétaux tertiaires du Sud-Ouest de la France. Bulletin de la Section des Sciences VIII: 197-212. 
ECKerT A. G. \& Hall B. D. 2006. - Phylogeny, historical biogeography, and patterns of diversification for Pinus (Pinaceae): Phylogenetic tests of fossil-based hypotheses. Molecular Phylogenetics and Evolution 40: 166-182. https://doi.org/10.1016/j. ympev.2006.03.009

ENDliCHer S. 1847. - Synopsis Coniferarum. Sangalli, Apud Scheitlin \& Zollikofer, 368 p. https://doi.org/10.5962/bhl. title. 15336

Erdei B., AKGÜN F. \& Lumaga M. R. B. 2010. - Pseudodioon akyoli gen. et sp. nov., an extinct member of Cycadales from the Turkish Miocene. Plant Systematics and Evolution 285: 33-49. https://doi.org/10.1007/s00606-009-0253-x

esteban L. G., De Palacios P., Casasus A. G. \& Fernandez G 2004. - Characterization of the xylem of 352 conifers. Investigación Agraria: Sistemas y Recursos Forestales 13: 452-478.

Evelpidou N., Koutsomichou I. \& Pirazzoli P. A. 2013. — Evidence of Late Holocene subsidence events in Sporades Islands: Skopelos and Alonnisos. Continental Shelf Research 69: 31-37. https://doi.org/10.1016/j.csr.2013.09.017

FAEGRI K. \& IVERSEN J. 1989. - Textbook of pollen analysis, in FAEGRI K., Kaland P. E. \& KrZYWINSKI K. (eds). John Wiley \& Sons, Chichester, $4^{\text {th }}$ ed., 328 p.

FANG J., WANG Z. \& TANG Z. (eds) 2011. — Atlas of Woody Plants in China. Species Distribution and Climate. Vol. 2. Springer-Verlag Berlin Heidelberg, 1902 p. https://doi.org/10.1007/978-3642-15017-3

FARJON A. 1996. - Biodiversity of Pinus (Pinaceae) in Mexico: speciation and palaeo-endemism. Botanical Journal of the Linnean Society 121 (4): 365-384. https://doi.org/10.1111/j.1095-8339.1996. tb00762.x

FARJON A. 2005. - A Monograph of Cupressaceae and Sciadopitys. Royal Botanic Gardens, Kew, 648 p.

Farjon A. \& Filer D. 2013. - An Atlas of the World's Conifers. An Analysis of their Distribution, Biogeography, Diversity and Conservation Status. Brill, 512 p. https://doi.org/10.1163/9789004211810

FauquetTe S., GUIOT J. \& SUC J.-P. 1998. - A method for climatic reconstruction of the Mediterranean Pliocene using pollen data. Palaeogeography, Palaeoclimatology, Palaeoecology 144: 183-201. https://doi.org/10.1016/S0031-0182(98)00083-2

Fauquette S., Suc J.-P., Jiménez-Moreno G., Micheels A., Jost A., Favre E., Bachiri-Taoufiq N., Bertini A., CletPellerin M., Diniz F., Farjanel G., Feddi N. \& Zheng Z. 2007. - Latitudinal climatic gradients in Western European and Mediterranean regions from the Mid-Miocene $(c .15 \mathrm{Ma})$ to the Mid-Pliocene (c.3.5 Ma) as quantified from pollen data, in Williams M., Haywood A., Gregory J., Schmidt D. N. (eds), Deep-Time Perspectives on Climate Change. Marrying the Signal from Computer Models and Biological Proxies. The Micropaleontological Society, The Geological Society, London Special Publications: 481-502. https://doi.org/10.1144/TMS002.22

FECHTER R. \& FALKNER G. 1990. — Weichtiere: Europäische Meeresund Binnenmollusken. Mosaik Verlag, München, 287 p.

GaUdry M. A. 1860. — Plantes fossiles de l'île d'Eubée. Paléontologie. Lettres de M. A. Gaudry à M. Elie de Beaumont. Comptes-rendus hebdomadaires des Séances de l'Académie des Sciences 50: 10931095. https://gallica.bnf.fr/ark:/12148/bpt6k3007r/f1105.item

GLÖER P. 2002. - Die Süßwassergastropoden Nord- und Mitteleuropas. Bestimmungsschlüssel, Lebensweise, Verbreitung. Die Tierwelt Deutschlands 73: 1-327.

Greguss P. 1967. - Fossil Gymnosperm Woods in Hungary from the Permian to the Pliocene. Akadémiai Kiadó, Budapest, $152 \mathrm{p}$.

Groom P. \& Rushton W. 1913. - The Structure of the Wood of East Indian Species of Pinus. Botanical Journal of the Linnean Society 41 (283): 457-490. https://doi.org/10.1111/j.1095-8339.1913. tb02486.x

GrYC V. \& SAKala J. 2010. - Identification of fossil trunks from Bükkábrány newly installed in the Visitor Centre of the Ipolytarnóc Fossils Nature Reserve (Novohrad - Nógrád Geopark) in
Northern Hungary. Acta Universitatis Agriculturae et Silviculturae Mendelianae Brunensis 58: 117-122. https://doi.org/10.11118/ actaun201058050117

Henry A. M. A. \& MCInTyre M. 1926. - The swamp cypresses, Glyptostrobus of China and Taxodium of America, with notes on allied genera. Proceedings of the Royal Irish Academy XXXVII (B): 90-116. https://www.jstor.org/stable/20490319

Hesse M., Halbritter H., Zetter R., Weber M., Buchner R., Frosch-Radivo A. \& Ulrich S. 2009. — Pollen terminology. An Illustrated Handbook. Springer Wein, New York, 264 p. https:// doi.org/10.1007/978-3-211-79894-2

Higgins M. D. \& Higgins R. 1996. - A Geological Companion to Greece and the Aegean. Cornell University Press/Duckworth Publishers, Ithaca, New-York/London, $240 \mathrm{p}$.

HuARD J. 1966. - Étude anatomique des bois de coniferes des couches à lignite néogènes des Landes. Mémoires de la Société géologique de France, nouvelle série 105: 1-85.

Iamandei E., IAmandei S. \& Diaconu F. 2011. — Fossil woods in the collection of Drobeta-Tr. Severin Museum. Acta Palaeontologica Romaniae 7: 199-218.

Iamandei S. 2000. - Pinuxylon parryoides (Gothan) Kräusel emend. van der Burgh, 1964, in Prăvăleni-Ociu Area (Middle Miocene), Southern Apuseni (Metallife-rous). Studii şi Cercetări de Geologie 45: 119-126.

IAMANDEI S. \& IAMANDei E. 2000. - Fossil Conifer Wood from Prăvăleni-Ociu, Metalliferous Mountains. Acta Paleontologica Romaniae 2: 201-212.

Iamandei S., Iamandei E. \& Miclăuş C. 2016. — A petrified wood from the lower Miocene of Valea Mare (Fărăoani, Bacău). Acta Palaeontologica Romaniae 12 (2): 21-27.

IAWA COMMITTEE 2004. - IAWA List of microscopic features for softwood identification, in Richter H. G., GROSSER D. HEINZ I. \& GASSON P. E. (eds). IAWA Journal 25: 1-70. https:// doi.org/10.1163/22941932-90000349

ICKERT-BOND S. M. 2001. - Reexamination of wood anatomical features in Pinus krempfii (Pinaceae). IAWA Journal 22: 355-365. https://doi.org/10.1163/22941932-90000382

JaCOBSHAGEN V. \& MATARANGAS D. 2004. — Nappe structure of the North Sporades (Greece): on the geological evolution of Alonissos Island. Bulletin of the Geological Society of Greece XXXVI: 1636-1642. https://doi.org/10.12681/bgsg.16567

JeOnG E. K., Kim K. SuZuki M. \& Uemura K. 2012. — Daijima-type conifer wood assemblage of the Hatamura Formation (Middle Miocene) in the Akita Prefecture, Japan. Geosciences Journal 16 (2): 115-125. https://doi.org/10.1007/s12303-012-0018-3

KEELEY J. E. 2012. - Ecology and evolution of pine life histories. Annals of Forest Science 69 (4): 445-453. https://doi.org/10.1007/ s13595-012-0201-8

KeLEPERTSIS A. E. 1973. - The Geology of the Alonissos and Peristera Islands. PhD Thesis (in Greek), $117 \mathrm{p}$.

KeLePerTsis A. 1975. - Geological Map of Greece 1:50000. Alonnisos and Skantzoura Islands. National Institute of Geology and Mining Exploration (IGME), Athens.

KVAČEK Z. \& Velitzelos E. 2000. - The cycadalean foliage "Encephalartos" gorceixianus Saporta (Zamiaceae) from the Lower Miocene of Greece (Kymi, Island of Evia) revisited. Feddes Repertorium 111 (3-4): 151-163. https://doi.org/10.1002/ fedr.20001110306

KVAČEK Z. \& Rember W. C. 2000. — Shared Miocene Conifers of the Clarkia Flora and Europe. Acta Universitatis Carolinae-Geologica 44 (1): 75-85.

KVAČeK Z., Velitzelos D. \& Velitzelos E. 2002. — Late Miocene Flora of Vegora Macedonia N. Greece. University of Athens, Korali publications, $175 \mathrm{p}$.

KVAČEK Z. 2014. - New fossil records of Ceratozamia (Zamiaceae, Cycadales) from the European Oligocene and lower Miocene. Acta Palaeobotanica 54 (2): 231-247. https://doi.org/10.2478/ acpa-2014-0012 
KvaČek Z., Teodoridis V., Mazouch P. \& Roiron P. 2014. Fossil seed cones of Pinus L. (sect. Pinus, subsect. Pinaster Loudon, Sula group) from the late Neogene and early Pleistocene of Europe. Palaeontographica, Abt. B: Palaeobotany - Palaeophytology 291 (1-6): 131-164.

Lecointre G. \& Koeniguer J. C. 1965. — Détermination d'un bois fossile récolté au Rio de Oro. Notas y Comunicaciones Instituto Geologico y Minero de España 80: 95-9.

LePage B. A. 2007. - The Taxonomy and Biogeographic History of Glyptostrobus Endlicher (Cupressaceae). Bulletin of the Peabody Museum of Natural History 48 (2): 359-426. https://doi.org/10. 3374/0079-032X(2007)48[359:TTABHO]2.0.CO;2

LePage B. A., Yang H. \& Matsumoto M. 2005. - The Evolution and Biogeographic History of Metasequoia, in LEPAGE B. A., Williams C. J. \& YANG H. (eds), The Geobiology and Ecology of Metasequoia. Springer, Netherlands: 3-114. https:// doi.org/10.1007/1-4020-2764-8_1

LINNAEUS C. 1758. - Systema naturae per regna tria naturae: secundum classes, ordines, genera, species, cum characteribus, differentiis, synonymis, locis. Tomus I. Editio decima, reformata. Holmiae. (Salvius) (1-4), 824 p. https://doi.org/10.5962/bhl.title.542

Li L., Jin J.-H. \& MANCHESTER S. R. 2018. - Cupressaceae fossil remains from the Paleocene of Carneyville, Wyoming. Review of Palaeobotany and Palynology 251: 1-13. https://doi.org/10.1016/j. revpalbo.2017.12.003

MA Q.-W., VicKULIN S., Li C.-S. \& WANG Y.-F. 2013. — Details of compressions of Glyptostrobus (Cupressaceae s.l.) from the Eocene of Fushun, NE China. Journal of Systematics and Evolution 51 (5): 601-608. https://doi.org/10.1111/jse.12035

Macaluso L., Martinetto E., Vigna B., Bertini A., Cilia A., TEODORIDIS V. \& KVAČEK Z. 2018. - Palaeofloral and stratigraphic context of a new fossil forest from the Pliocene of NW Italy. Review of Palaeobotany and Palynology 248: 15-33. https:// doi.org/10.1016/j.revpalbo.2017.08.005

MaI D. H. 1995. - Tertiäre Vegetationsgeschichte Europas. Gustav Fisher Verlag, Jena, 691 p.

MAi D. H. \& VeliTZELOS E. 1997. — Paläokarpologische Beiträge zur jungtertiären Flora von Vegora (Nordgriechenland). Feddes Repertorium 108 (7-8): 507-526. https://doi.org/10.1002/fedr.19971080703

Mai D. H. \& Velitzelos E. 2002. — Über fossile Pinaceen-Reste im Jungtertiär von Griechenland. Feddes Repertorium 103 (1-2): 1-18. https://doi.org/10.1002/fedr.19921030102

Mai D. H. \& Velitzelos E. 2007. - The fossil flora of Kallithea (Rhodes, Greece) at the Pliocene/Pleistocene boundary. Palaeontographica Abteilung B 277 (1-4): 75-99.

MANCHESTER S. R. 1999. - Biogeographical Relationships of North American Tertiary Floras. Annals of the Missouri Botanical Garden 86: 472-522. https://doi.org/10.2307/2666183

MartinetTo E., Scardia G. \& Varrone D. 2007. — Magnetobiostratigraphy of the Stura di Lanzo Fossil Forest succession (Piedmont, Italy). Rivista Italiana di Paleontologia e Stratigrafia 113: 109-125. https://doi.org/10.13130/2039-4942/6362

MarTinetTo E. \& MACALUSO L. 2018. — Quantitative application of the whole-plant concept to the Messinian-Piacenzian flora of Italy. Fossil Imprint 74 (1-2): 77-100.

Martinetto E., Momohara A., Bizzarri R., Baldanza A., Delfino M., Esu D. \& SARDELLA R. 2017. — Late persistence and deterministic extinction of "humid thermophilous plant taxa of East Asian affinity" (HUTEA) in southern Europe. Palaeogeography, Palaeoclimatology, Palaeoecology 467: 211-231. https:// doi.org/10.1016/j.palaeo.2015.08.015

Martinetto E., Monegato G., Irace A., Vaiani S. C. \& Vassio E. 2015. - Pliocene and Early Pleistocene carpological records of terrestrial plants from the southern border of the Po Plain (northern Italy). Review of Palaeobotany and Palynology 218:148166. https://doi.org/10.1016/j.revpalbo.2014.10.007

Mayor A. 2000. — The First Fossil Hunters: Paleontology in Greek and Roman Times. Princeton University Press, 363 p.
Mcneill J., Barrie F. R., Burdet H. M., Demoulin V., HawkSWorth D. L., Marhold K., Nicolson D. H., Prado J., Silva P. C., Skog J. E., Wiersema J. H. \& Turland N. J. 2006. International Code of Botanical Nomenclature (Vienna Code), adopted by the Seventeenth International Botanical Congress Vienna, Austria, July 2005. A. R. G. Gantner Verlag KG. Regnum Vegetabile 146: 1-568.

Miller C. N. 1976. - Early evolution in the Pinaceae. Review of Palaeobotany and Palynology 21: 101-117. https://doi.org/10.1016/00346667(76)90024-5

Miller C. N. 1973. - Silicified cones and vegetative remains of Pinus from the Eocene of British Columbia. Contributions from the Museum of Paleontology, the University of Michigan 24 (10): 101-118. http://hdl.handle.net/2027.42/48477

Neubauer T. A., Harzhauser M., Kroh A., Georgopoulou E. \& MANDiC O. 2014. - The FreshGEN Database: Freshwater Gastropods of the European Neogene. http://www.marinespecies. org/freshgen (last accessed September 2018).

Nishida M. \& Nishida H. 1995. — Pinoid Woods with Resin Canals from the Upper Cretaceous of Hokkaido and Saghalien. Journal of Plant Research 108: 161-170. https://doi.org/10.1007/ BF02344340

OguRA Y. 1944. - Notes on fossil woods from Japan and Manchoukuo. Japanese Journal of Botany 13 (3): 345-365.

PAPANIKOlaOU D., AlEXANDRi M., NOMiKOU P. \& BAllas D. 2002. - Morphotectonic structure of the western part of the North Aegean Basin based on swath bathymetry. Marine Geology 190: 465-492. https://doi.org/10.1016/S0025-3227(02)00359-6

Pe-Piper G., Matarangas D. \& Jacobshagen V. 1996. - The mesozoic metavolcanic rocks of Alonnisos and Kyra Panagia islands, Sporades, Greece. Neues Jahrbuch fur Mineralogie, Monatshefte 6: 251-263.

Petrescu I. \& BiCAN-BRişan N. 2004. - The presence of some Pinuxylon Gothan 1906 woods in the Badenian salt from Ocna Dej (NW Romania). Acta Palaeontologica Romaniae 4: 345-349.

Phillips E. W. J. 1941. — The Identification of Coniferous Woods by their Microscopic Structure. Journal of the Linnean Society of London, Botany 52 (343): 259-320. https://doi. org/10.1111/j.1095-8339.1941.tb01390.x

Popov S. V., Shcherba I. G., Ilyina L. B., Nevesskaya L. A., ParaMONOVA N. P., KhONDKARIAN S. O. \& MAgYar I. 2006. - Late Miocene to Pliocene palaeogeography of the Paratethys and its relation to the Mediterranean. Palaeogeography, Palaeoclimatology, Palaeoecology 238: 91-106. https://doi.org/10.1016/j. palaeo.2006.03.020

Poulimenos G. \& KarKanas P. 1998. - Messinian carbonate and alluvial fan sedimentation in Alonnisos Island, Greece: Sedimentary response to basement controls, inversion tectonics and climatic fluctuations. Geological Journal 33 (3): 159-175. https:// doi.org/10.1002/(SICI) 1099-1034(199807/09)33:3<159::AIDGJ787>3.0.CO;2-L

Price R. A., Liston A. \& Strauss S. H. 1998. - Phylogeny and systematics of Pinus, in Richardson D. M. (ed.), Ecology and Biogeography of Pinus. Cambridge University Press, Cambridge: 49-68.

PrIVÉ C. 1972. - Sur la présence de bois de pins fossiles dans le Cantal. Actes du 97e congrès national des sociétés savantes, Nantes IV:137-158.

QI G. F., YANG J. J., XU R. H. \& HU D. H. 2005. - Flora of Angiospermous Fossil Woods from Wuhan, China. Science Press, Beijing, 170 p. (in Chinese).

RÖsSLER W. 1937. — Pliozäne Koniferenhölzer aus der Um-gebung von Gleichenberg in Steiermark. Mitteilungen des Naturwissenschaftlichen Vereines für Steiermark 74: 64-97.

SAKALA J., SelmeCZI I. \& HABly L. 2018. — Reappraisal of Greguss' fossil wood types and figured specimens from the Cenozoic of Hungary: overview, corrected geology and systematical notes. Fossil Imprint 74: 101-114. 
SAPORTA G. DE 1874. — Sur la présence d'une Cycadée dans le dépôt miocène de Koumi (Eubée). Comptes rendus hebdomadaires des Séances de l'Académie des Sciences, Paris 78: 1318-1321. https:// gallica.bnf.fr/ark:/12148/bpt6k3035z/f1191.item

SAUVAGE M. 1861. - Observations sur la géologie d'une partie de la Grèce continentale et de l'île d'Eubée, in Dictionnaire universel théorique et pratique du Commerce et de la Navigation. Tome 2. Paris, 118 p. https://gallica.bnf.fr/ark:/12148/bpt6k35391r

SHAW G. R. 1914. - The genus Pinus. Publications of the Arnold Arboretum, vol. 5, 96 p. https://biodiversitylibrary.org/page/20894343

SCHNEIDER H. 1972. - Beobachtungen zum kontinentalen Neogen Thessaliens Griechenland. Neues labrbuch für Geologie und Paläontologie, Monatshefte 3: 183-195.

SChneider H. E. \& Velitzelos E.1973. - Jungtertiäre Pflanzenfunde aus dem Becken von Vegora in West-Mazedonien (Griechenland). Erste Mitteilung. Annales Musei Goulandris 3: 173-180.

SCHNeider H. E. \& Velitzelos E. 1976. — Eine Neogenflora im Becken von Vegora (NW-Makedonien). Bulletin de la Société géologique de France 18 (2): 2-204. https://doi.org/10.2113/ gssgfbull.S7-XVIII.2.204

SHIMAKURA M. 1936. - Studies on fossil woods from Japan and adjacent lands contribution I. Science reports of the Töhoku University 18 (3): 267-310. http://hdl.handle.net/10097/00106718

Süss H. \& Velitzelos E. 1993. - Eine neue Protopinaceae der Formgattung Pinoxylon Knowlton emend. Read, P. parenchymatosum sp. nov., aus tertiären Schichten der Insel Lemnos, Griechenland. Feddes Repertorium 104 (5-6): 335-341. https:// doi.org/10.1002/fedr.19931040508

Süss H. \& Velitzelos E. 1994. — Zwei neue tertiäre Hölzer der Gattung Pinoxylon Knowlton emend. Read aus dem Versteinerten Wald von Lesbos, Griechenland. Feddes Repertorium 105 (7-8): 403-423. https://doi.org/10.1002/fedr.19941050702

Süss H. \& Velitzelos E. 2009. - Zwei neue fossile Hölzer der Morphogattung Pinoxylon Knowlton emend. Read aus dem Tertiär der Insel Lesbos, Griechenland. Feddes Repertorium 120 (1-2): 3-14. https://doi.org/10.1002/fedr.200811191

Süss H. \& VelitZelos E. 2010. - Lesbosoxylon gen. nov., eine neue Morphogattung mit dem Typus Lesbosoxylon ventricosuradiatum sp. nova aus dem Tertiar der Insel Lesbos, Griechenland. Feddes Repertorium 121 (1-2): 18-26. https://doi.org/10.1002/ fedr.201011124

TAO J. R., YANG J. J. \& WANG Y. F. 1994. - Miocene wood fossils and paleoclimatein Inner Mongolia. Acta Botanica Yunnanica 16 (2): 111-116 (in Chinese, with English abstract).

TEODORIDIS V. \& SAKALA J. 2008. — Early Miocene conifer macrofossils from the Most Basin (Czech Republic). Neues Jahrbuch für Geologie und Paläontologie, Abhandlungen 250: 287-312. https:// doi.org/10.1127/0077-7749/2008/0250-0287

Teodoridis V., Bruch A. A., Vassio E., Martinetto E. KVAČEK Z. \& STUCHLIK L. 2017. - Plio-Pleistocene floras of the Vildštejn Formation in the Cheb Basin, Czech Republic - A floristic and palaeoenvironmental review. Palaeogeography, Palaeoclimatology, Palaeoecology 467: 166-190. https://doi.org/10.1016/j. palaeo.2015.09.038

TidWell W., Parker L. R. \& FolkMan Y. K. 1986. - Pinuxylon woolardii sp. nov., a new petrified taxon of Pinaceae from the Miocene basalts of Eastern Oregon. American Journal of Botany 73 (11): 1517-1524. https://doi.org/10.1002/j.1537-2197.1986.tb10901.x

TSOUKala E. \& Melentis J. 1994. - Deinotherium giganteum Kaup (Proboscidea) from Kassandra peninsula (Chalkidiki, Macedonia Greece). Geobios 27: 633-640. https://doi.org/10.1016/S00166995(94)80262-9

UNGER F. 1850. - Die Gattung Glyptostrobus in der Tertiär-Formation. Sitzungsberichte der Kaiserlichen Akademie der Wissenschaften in Wein, Mathematisch-Naturwissenschafliche Classe 5: 434-435.

UNGER F. 1862. - VIII. Die fossile Flora von Kumi auf Euboea, in Wissenschaftliche Ergebnisse einer Reise in Griechenland und in den jonischen Inseln. Wilhelm Braumüller, Wien: 143-150.
VAN Der Burgh J. 1964. — Hölzer der niederrheinischen Braunkohlenformation, 1.Hölzer der braunkohlengru-ben "Anna" zu Haanrade (Niederländisch Limburg). Acta Botanica Neerlandica 13: 250-301. https://doi.org/10.1111/j.1438-8677.1964. tb00156.x

VAN DER BURGH J. 1973. - Hölzer der niederrheinischen Braunkohlenformation. 2. Hölzer der Braunkohlengruben "Maria Theresia" zu Herzogenrath, "Zukunft West" zu Eschweiler und "Victor" (Zülpich-Mitte) zu Zülpich. Nebst einer systematisch-anatomischen Bearbeitung der Gattung Pinus L. Review of Palaeobotany and Palynology 15: 73-275. https://doi.org/10.1016/00346667(73)90001-8

Vassio E., Martinetto E., Dolezych M. \& van der Burgh J. 2008. - Wood anatomy of the Glyptostrobus europaeus "wholeplant" from a Pliocene fossil forest of Italy. Review of Palaeobotany and Palynology 151 (3-4): 81-89. https://doi.org/10.1016/j. revpalbo.2008.02.006

Velitzelos E. \& SCHNEIDER H. E. 1977. - Jungtertiäre Pflanzenfunde aus dem Becken von Vegora in West-Mazedonien (Griechenland). Annales Musei Goulandris 3: 173-180.

VelitZELOS E. \& GREGOR H.-J. 1990. - Some aspects of the neogene floral history in Greece. Review of Palaeobotany and Palynology 62: 291-307. https://doi.org/10.1016/0034-6667(90)90092-W

Velitzelos E. \& SChNeider H. E. 1979. — Jungtertiäre Pflanzenfunde aus dem Becken von Vegora in West-Mazedonien. 3. Mitteilung: Eine Fächerpalme (Chamaerops humilis L.). Annales géologiques des Pays helléniques 29: 796-799.

Velitzelos D., Bouchal J. M. \& Denk T. 2014. - Review of the Cenozoic floras and vegetation of Greece. Review of Palaeobotany and Palynology 204: 56-117. https://doi.org/10.1016/j. revpalbo.2014.02.006

VickUlin S. V., MA Q.-W., ZhiLin S. G. \& LI C.-S. 2003. — On cuticular compressions of Glyptostrobus europaeus (Taxodiaceae) from Kaydagul Formation (Lower Miocene) of the Central Kazakhstan. Acta Botanica Sinica 45 (6): 673-680

VIRLET M. T. 1833. - Notes géologiques sur les îles du nord de la Grèce, et, en particulier, sur un terrain de calcaire d'eau douce à lignites. Annales des Sciences naturelles 30: 160-167. https:// biodiversitylibrary.org/page/5978675

VIRLET M. T. 1835. - II. Fresh water formation in Greece with Lignites, in THOMSON D. ROBERT (ed.), Records of General Science, Scientific Intelligence, vol. 77.

VozENIN-SERRA C. 1971. - Notes sur des bois mésozoïques et cénozoïques du Viet-Nam et Cambodge. Sur un bois "néogène" de l'île de Bach Long Li. Archives géologiques du Viet-Nam 14: 31-39.

Wang H. B., Oskolski A. A., JacQUes F. M. B., WANG Y.-H. \& ZHOU Z.-K. 2017. — Lignified woods of Pinus (Pinaceae) from the late Miocene of central Yunnan, China, and their biogeographic and paleoclimatic implications. Palaeoworld 26: 553-565. https://doi.org/10.1016/j.palwor.2016.06.003

WANG X. Q. \& RAN J. H. 2014. - Evolution and biogeography of gymnosperms. Molecular Phylogenetics and Evolution 75: 24-40. https://doi.org/10.1016/j.ympev.2014.02.005

Williams C. J., Mendell E. K., Murphy J., Court W. M., JOHNSON A. H. \& Richter S. L. 2008. - Paleoenvironmental reconstruction of a Middle Miocene forest from the western Canadian Arctic. Palaeogeography, Palaeoclimatology, Palaeoecology 261: 160-176. https://doi.org/10.1016/j.palaeo.2008.01.014

Xu Q., Zhou W., Kodrul T. M., Naugolnykh S. V. \& Jin J. 2015. - Late Eocene white pines (Pinus subgenus Strobus) from southern China. Scientific Reports 5: 16390, 1-12. https:// doi.org/10.1038/srep16390 https://doi.org/10.1038/srep16390

YANG J. J., QI G. F. \& XU R. H. 1990. — Studies on fossil woods excavated from the Dabie Mountains. Scientia Silvae Sinicae 28 (4): 379-383 (in Chinese, with English abstract).

YANG J. J., QI G. F., Xu R. H. \& YANG L. M. 1996. — Studies on three gymnospermous fossil woods excavated from Wuhan area. Liaoning Geology (4): 263-273 (in Chinese, with English abstract). 
Yi T.-M., Li C.-S., Jiang X.-M. \& Wang Y. 2002. — Pliocene Rhododendron and Pinus fossil woods of Yunnan Province and paleoclimate. Journal of Palaeogeography 4 (4): 90-98 (in Chinese with English abstract).

Yi T.-M., Li C.-S \& JiAng X.-M. 2005. - Conifer Woods of the Pliocene Age from Yunnan, China. Journal of Integrative Plant Biology 47 (3): 264-270. https://doi.org/10.1111/j.17447909.2005.00041.x
Zhang W., Li Y., Zheng S. L., Li N., Wang Y. D., Yang X. J., YANG J. J., YI T. M. \& FU X. P. 2008. - Fossil Woods of China. China Forestry Press, Beijing, 356 p. (in Chinese).

Zidianakis G., Iliopoulos G., Zelilidis A. \& Kovar-Eder J. 2016. - Pinus remains from the Pitsidia plant assemblage document coastal pine forests in southern Crete during the late Miocene. Review of Palaeobotany and Palynology 235: 11-30. https://doi.org/10.1016/j.revpalbo.2016.09.003

Submitted on 10 August 2018; accepted on 15 October 2018; published on 7 February 2019. 